\title{
Heteroarotinoids Inhibit Head and Neck Cancer Cell Lines in Vitro and in Vivo Through Both RAR and RXR Retinoic Acid Receptors
}

\author{
David Zacheis, ${ }^{\dagger}$ Arindam Dhar, ${ }^{\S}$ Shennan Lu, ${ }^{\prime \prime}$, Matora M. Madler, ${ }^{\ddagger}$ J ozef Klucik, ${ }^{\ddagger}$ Chad W. Brown, ${ }^{\ddagger}$ \\ Shengquan Liu, ${ }^{\ddagger}$ Francis Clement, $\neq$ Shankar Subramanian, $\neq$ G. Mahika Weerasekare, ${ }^{\ddagger}$ K. Darrell Berlin, $*, \neq$ \\ Michael A. Gold, ${ }^{\S}$ J ohn R. Houck, J r., † Kenneth R. Fountain,,${ }^{\dagger}$ and Doris M. Benbrook*,\$,l \\ Departments of Otorhinolaryngology, Obstetrics and Gynecology, and Biochemistry and Molecular Biology, \\ University of Oklahoma Health Sciences Center, P.O. Box 26901, Oklahoma City, Oklahoma 73190, \\ Department of Chemistry, Oklahoma State University, Stillwater, Oklahoma 74078, and Department \\ of Chemistry, Truman State University, Kirksville, Missouri 63501
}

Received J une 8, 1999

A class of less toxic retinoids, called heteroarotinoids, was evaluated for their molecular mechanism of growth inhibition of two head and neck squamous cell carcinoma (HNSCC) cell lines SCC-2 and SCC-38. A series of 14 heteroarotinoids were screened for growth inhibition activity in vitro. The two most active compounds, one that contained an oxygen heteroatom (6) and the other a sulfur heteroatom (16), were evaluated in a xenograph model of tumor establishment in nude mice. Five days after subcutaneous injection of $10^{7} \mathrm{SCC}-38$ cells, groups of $5 \mathrm{nu} / \mathrm{nu}$ mice were gavaged daily ( 5 days/week for 4 weeks) with $20 \mathrm{mg} / \mathrm{kg} / \mathrm{day}$ of all-transretinoic acid (t-RA, 1), $10 \mathrm{mg} / \mathrm{kg} /$ day of $6,10 \mathrm{mg} / \mathrm{kg} /$ day of $\mathbf{1 6}$, or sesame oil. After a few days, the dose of t-RA (1) was decreased to $10 \mathrm{mg} / \mathrm{kg} /$ day to alleviate the side effects of eczema and bone fracture. No significant toxic effects were observed in the heteroarotinoid groups. All three retinoids caused a statistically significant reduction in tumor size as determined by the Student t-test $(P<0.05)$. Complete tumor regression was noted in 3 of 5 mice treated with t-RA (1), 4 of 5 mice treated with $\mathbf{1 6}, 1$ of 5 mice treated with $\mathbf{6}$, and 1 of 5 mice treated with sesame oil. Reverse transcriptase polymerase chain reaction (RT-PCR) was used to determine that the expression levels of $\operatorname{RAR} \alpha, \operatorname{RXR} \alpha$, and $\operatorname{RXR} \beta$ were similar in the two cell lines, while $\operatorname{RAR} \beta$ expression was higher in SCC-2 over SCC-38, and RAR $\gamma$ expression was higher in SCC-38 over SCC-2. Receptor cotransfection assays in CV-1 cells demonstrated that $\mathbf{1 6}$ was a potent activator of both RAR and RXR receptors, while $\mathbf{6}$ was sel ective for the RXR receptors. Transient cotransfection assays in CV-1 cells using an AP-1 responsive reporter plasmid demonstrated that t-RA (1), 6, and $\mathbf{1 6}$ each inhibited AP-1-driven transcription in this cell line. In conclusion, the growth inhibition activity of the RXR-selective $\mathbf{6}$ and the more potent growth inhibition activity of the RAR/RXR pan-agonist $\mathbf{1 6}$ implicate both RARs and RXRs in the molecular mechanism of retinoid growth inhibition. Moreover, the chemoprevention activity and the lack of toxicity of heteroarotinoids demonstrate their clinical potential in head and neck cancer chemoprevention.

\section{Introduction}

Retinoids have been known to elicit useful pharmacological responses in a variety of disorders. ${ }^{1}$ Activities of endogenous retinoids such as trans-retinoic acid (tRA, 1), 9-cis-retinoic acid (9-c-RA, 2), and 13-cis-retinoic acid (13-c-RA, 3) are well-known in cancer therapy, although all have some toxic characteristics. ${ }^{2}$ The synthetic retinoid 4-(hydroxyphenyl)retinamide (4, 4-HPR), currently under clinical investigation, is also known to possess some undesirable properties such as night blindness, although it appears to be dose-dependent and reversible. ${ }^{3}$

Certain heteroarotinoids have demonstrated anticancer activity as well as low toxicity. ${ }^{4-8}$ We now report

* Corresponding authors. For biology: e-mail, Doris-Benbrook@ OUHSC-edu. For chemistry: e-mail, kdberlin@bmb-fsl.biochem. okstate.edu.

† Department of Otorhinolaryngology, OUHSC.

$\S$ Department of Obstetrics and Gynecology, OUHSC.

" Department of Biochemistry and Molecular Biology, OUHSC.

₹ Department of Chemistry, OSU .

$\nabla$ Department of Chemistry, TSU.

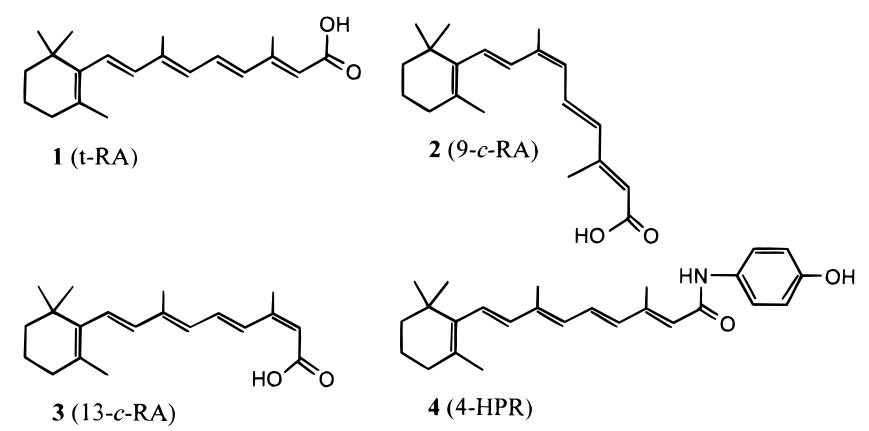

the growth inhibitory activity of a variety of heteroarotinoids 5-19 (Chart 1) against head and neck squamous cell carcinoma (HNSCC) cell lines, SCC- 2 and SCC-38. The heteroarotinoids possess a range of flexibility in terms of the linking groups attached to the aryl ring and, in most cases, between two aryl rings. It was reasoned that such flexibility might better allow accommodation of the molecule in the receptor site and 


\section{Chart 1}<smiles>CCOC(=O)c1ccc(OC(=O)c2ccc3c(c2)C(C)(C)CCO3)cc1</smiles><smiles>CC1(C)CCOc2ccc(C(=O)Oc3ccc(C=N)cc3)cc21</smiles><smiles>COC(=O)c1ccc(C(=O)Oc2c(C)cc3c(c2C)C(C)(C)C=C(C)O3)cc1</smiles><smiles>COC(=O)c1ccc(C(=O)Oc2c(C)cc3c(c2C)C(C)(C)CC(C)(C)O3)cc1</smiles><smiles>COC(=O)c1ccc(N(C(=O)c2ccc3c(c2)C(C)(C)CCO3)C(C)C)cc1</smiles><smiles>CCOC(=O)c1ccc(OC(=O)c2cc3c(cc2OC)C(C)(C)COC3(C)C)cc1</smiles><smiles>CCOC(=O)c1ccc(OC(=O)c2cc3c(cc2OC)C(C)(C)CCC3C)cc1</smiles><smiles>CC(=Cc1ccc(C(=O)O)cc1)c1ccc2c(c1)C(C)(C)CO2</smiles><smiles>CCOC(=O)/C=C(C)/C=C/C=C(\C)c1ccc2c(c1)OCCO2</smiles>

12<smiles>COC(=O)c1ccc(C(=O)Nc2ccc3c(c2)C(C)(C)CC(C)(C)S3)cc1</smiles><smiles></smiles><smiles>CCOC(=O)c1ccc(OC(=O)c2ccc3c(c2)C(C)(C)CCN3C(C)C)cc1</smiles>

therefore lead to an activated complex of ligandreceptor. The area of ligand-receptor binding has been reviewed. ${ }^{9}$

Head and neck cancers often arise from a field of epithelial injury caused by carcinogens in tobacco smoke which, in turn, leads to multiple premalignant lesions and the risk of primary and second primary tumor formation. ${ }^{10,11}$ Retinoids have been shown to reverse oral premalignant lesions and prevent second primaries in patients treated for head and neck cancers. The use of retinoids for the prevention and treatment of head and neck cancers was inspired by the observations that vitamin A deficiency caused keratinizing squamous metaplasia in mucociliary epithelium and that replenishment of retinoids restored normal epithelial differentiation.12,13 Leukoplakia and erythroplakia are premalignant head and neck mucosal lesions. Several studies have attempted to use retinoids to prevent or reverse these lesions back to normal mucosa in highrisk patients. In a low-dose experiment that showed minimal toxicity to the patients, the natural retinoid 13-c-RA (3) was found to be superior to $\beta$-carotene in reducing the rate of oral leukoplakia progression. ${ }^{14}$ The synthetic retinoid 4-HPR (4) has been shown to decrease relapses and new localizations of surgically treated oral leukoplakia from $30 \%$ to $6 \% .^{15}$

Many head and neck epithelial malignancies are multifocal, and the development of a second primary tumor either during treatment or after successful treatment for a primary tumor occurs at a rate of $4-7 \%$ year. ${ }^{16} \mathrm{~A}$ population of these patients had significant reductions in development of second primary tumors when treated with 13-c-RA (3) for a median follow-up of 54 months. ${ }^{17}$ Despite these encouraging results, a large number of relapses have been detected upon cessation of certain agents, and there have been numerous side effects, especially at high doses. These side effects include mucocutaneous dryness, dermatitis, conjunctivitis, photodermatosis, impaired night vision, hypertriglyceridemia, and transient increases in serum liver function enzymes. Efforts to prevent relapses and to reduce toxicity have included co-treatment with $\alpha$-tocopherol and the development of synthetic retinoids. ${ }^{7,18}$

Prior to clinical application, the chemoprevention activities of retinoids are usually evaluated against HNSCC cell lines in vitro and in animal models in vivo. Although vitamin $A$ is the least toxic of the natural retinoids, it is also the weakest inhibitor of growth in HNSCC cell lines in vitro and in xenograph growth in vivo, followed by $13-c-R A$ (3). ${ }^{19-24}$ The reduced toxicity of certain heteroarotinoids ${ }^{7}$ prompted an evaluation in the present study to determine if such heterocycles inhibited the growth of HNSCC cell lines in vitro and in vivo and to explore the molecular mechanism of action of such agents.

\section{Results and Discussion}

Chemistry. The discussion of the chemistry is in an order with respect to various properties of the selected heteroarotinoids. Known activities of $5,{ }^{7} 6,{ }^{7} 12,614,{ }^{4}$ and $\mathbf{1 5}^{7}$ in certain assays prompted us to make a change to a somewhat different flexible linking group as in $\mathbf{7}$. Although some amide linking groups have been exam- 


\section{Scheme 1}

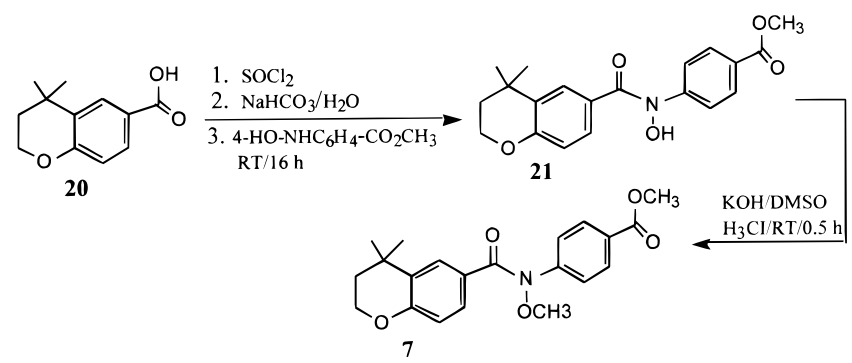

ined for useful activity 25 and even for RAR $\alpha$ selectivity, ${ }^{26}$ no record of the use of a $\mathrm{C}(\mathrm{O})-\mathrm{N}$-methoxy linker could be found in the literature. The excess bulk of this group was considered as altering the rotational barrier of the $\mathrm{C}-\mathrm{N}$ bond and thereby possibly influencing receptor binding and activation.

Generation of the acid chloride from known $\mathbf{2 0}^{8}$ and subsequent treatment with the appropriate hydroxylamine as shown gave $\mathbf{2 1}$ (Scheme 1). O-Methylation proceeded under mild conditions to yield $7(48 \%)$.

Creating and assessing ester $\mathbf{8}$ for useful activity was considered a test of the influence on activity by flanking methyl groups of the aryl ring with respect to freedom of rotation of the internal ester linkage. In addition, it is known ${ }^{5,7}$ that alkyl groups adjacent to the heteroatom have a positive influence on biological activity. Thus, ester 8 possesses both such features. Excess methylmagnesium bromide added to known $\mathbf{2 2}^{27}$ in boiling ether over $48 \mathrm{~h}$ led to lactol $\mathbf{2 3}$ (Scheme 2). Dehydration of $\mathbf{2 3}$ under standard conditions yiel ded ether $\mathbf{2 4}$. Direct esterification of $\mathbf{2 4}$ gave new ester $\mathbf{8}$ (50\%) which was purified by chromatography.

Surprisingly, when $\mathbf{2 2}$ was treated with the same excess of methyl Grignard reagent as used to obtain $\mathbf{2 3}$, but in THF, ether $\mathbf{2 5}$ (76\%) formed (Scheme 3). Perhaps the much longer reaction time was significant, but the solvent was found to be important as well. Esterification of $\mathbf{2 5}$ under the usual conditions produced the target ester ether 9 (52\%). This heteroarotinoid 9 possessed the geminal methyl flanking group that enhanced activity in several assays in related systems which contained more rigid linking groups attached to the aryl ring. ${ }^{5}$ Consequently, an assessment could be made of the alteration in activity between $\mathbf{8}$ and $\mathbf{9}$.

Retaining the flexible ester linkage between the two aryl rings was desirable in $\mathbf{1 0}$. In part, the rationale for $\mathbf{1 0}$ was based on the strong activity of (E)-4-[2(5,6,7,8-tetrahydro-5,5,8,8-tetramethyl-2-naphthal enyl)1-propenyl]benzoic acid (TTNPB), although it is very toxic. ${ }^{7}$ The incorporation of an oxygen atom into system $\mathbf{1 0}$ might reduce toxicity sufficiently to be tol erable and yet retain useful activity. Dimethylation of $\mathbf{2 6}$ as shown was facile and gave $\mathbf{2 7}$ in high yield (84\%) (Scheme 4). Base-catalyzed hydrolysis of $\mathbf{2 7}$ led to acid $\mathbf{2 8}$ (69\%), a reported compound ${ }^{28}$ but not previously well-characterized. Reduction of $\mathbf{2 8}$ to $\mathbf{2 9}$ was straightforward, and alcohol $\mathbf{2 9}$ was cyclized with the incorporation of an acetone unit to yield ether $\mathbf{3 0}$ (75\%). Acetylation of $\mathbf{3 0}$ proved more difficult than anticipated, but the use of $\mathrm{H}_{3} \mathrm{CNO}_{2}$ with $\mathrm{AlCl}_{3}$ and $\mathrm{AcCl}$ was successful and gave 31 (51\%) without cleavage of the methoxy ether group. Oxidative cleavage of the acetyl group in $\mathbf{3 1}$ to give acid 32 gave only a modest yield (21\%) due to si de reactions.
The use of a combination of $\mathrm{LiOCl} / \mathrm{Cl}$ orox was ultimately successful. Esterification of $\mathbf{3 2}$ required a long reaction time to obtain 10, apparently due to the increased steric hindrance around the carbonyl group of $\mathbf{3 2}$.

In view of the known toxicity of TTNPB, ${ }^{7}$ the synthesis of the close anal ogue $\mathbf{1 1}$ (Scheme 5) would al so serve as a model for comparison of activity with that of heteroarotinoid 10. Acetylation of known ${ }^{29} \mathbf{3 3}$ also was demanding in terms of avoiding or minimizing cleavage of the ether linkage in $\mathbf{3 0}$. Using the conditions outlined resulted in the generation of $\mathbf{3 4}$ (75\%). As with the conversion of $\mathbf{3 1}$ to $\mathbf{3 2}$, generation of acid $\mathbf{3 5}$ from ketone 34 was slow because of hindrance, although $\mathbf{3 5}$ was isolated in moderate yield (44\%). Esterification of 35 to produce $11(67 \%)$ required a long reaction time as anticipated.

The unusual heteroarotinoid $\mathbf{1 3}$ was selected for inclusion in the study since it possessed a rigid long side chain and contained two heteroatoms in the fused ring unit. Other heteroarotinoids with long side chains had exhibited strong activity in several assays. ${ }^{5,6}$ The influence of two heteroatoms could also be assessed. The addition of a nearly 3-fold excess of vinylmagnesium bromide to commercial $\mathbf{3 6}$ resulted in essentially a quantitative yield of slightly crude 37 (Scheme 6). Conversion of the vinyl alcohol $\mathbf{3 7}$ to the phosphonium salt $38(85 \%)$ was effected by conditions previously developed. ${ }^{5,7}$ Generation of the Wittig reagent of $\mathbf{3 8}$ as shown was followed by the addition of ethyl 3-methyl4-oxocrotonate in a normal condensation to provide heteroarotinoid $\mathbf{1 3}$, albeit in modest yield $(28.8 \%)$.

The flexi ble heteroarotinoid $\mathbf{1 6}$ could be obtained via the conversion of $\mathbf{3 9} \rightarrow \mathbf{4 0} \rightarrow \mathbf{4 1} \rightarrow \mathbf{1 6}$ as illustrated (Scheme 7). The nitration of known 39 afforded the 6 -isomer $\mathbf{4 0}$ in modest yield (27\%) since other nitrated products appeared to have formed. Reduction of the nitro group in $\mathbf{4 0}$ to the amino function in $\mathbf{4 1}$ (50\%) progressed reasonably well under mild conditions. NAcylation of $\mathbf{4 1}$ with the acid chloride shown produced the target 16 (72\%), again under quite mild conditions.

Biology. 1. In Vitro Growth Inhibition Screen. A series of retinoids were screened for growth inhibition activity in the SCC-2 and SCC-38 HNSCC cell lines. The activities of 14 heteroarotinoids containing a sulfur heteroatom (14-16), an oxygen heteroatom (5-10, 12, $\mathbf{1 3 )}$, or a nitrogen heteroatom (17-19), as well as a structurally related arotinoid (11) void of a heteroatom, were compared to that of 9-c-RA (2) (Table 1). Although most of the compounds inhibited growth, some of them stimulated growth. Three of the compounds with oxygen heteroatoms $(\mathbf{5}, \mathbf{8}, \mathbf{9})$ had opposite effects in the two cell lines. The Student t-test was used to demonstrate that there were no statistically significant differences between the responses of the two cell lines to the entire set of retinoids $(P>0.05)$ or between the activities of groups with different types of heteroatoms $(P>0.05)$. The oxygen heteroarotinoid $\mathbf{6}$ and sulfur heteroarotinoid $\mathbf{1 6}$ were the most active in both cell lines and were therefore chosen for evaluation in a xenograft model.

2. Xenograft Model. The $\mathbf{6}$ and $\mathbf{1 6}$ compounds were evaluated for biological activity in a xenograft nude mouse model. Athymic nu/nu mice were injected subcutaneously with $10^{7}$ SCC-2 or SCC-38 cells. The effects of retinoids in mice injected with SCC- 2 cells could not 


\section{Scheme 2}

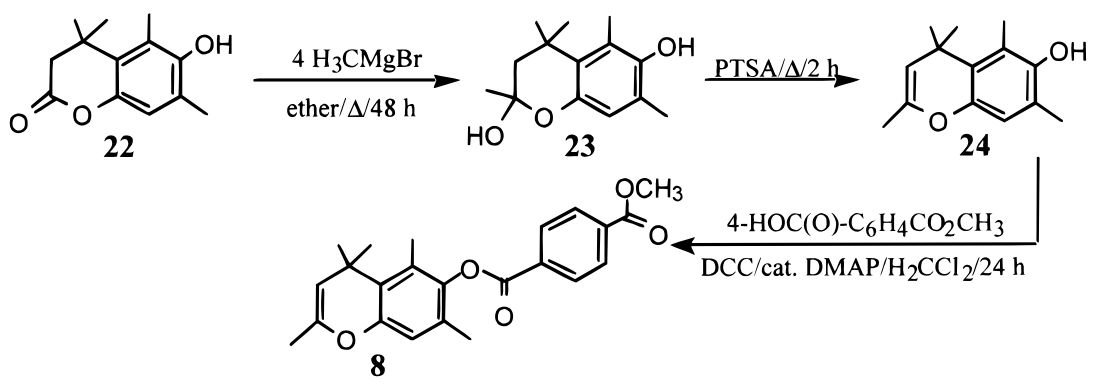

\section{Scheme 3}

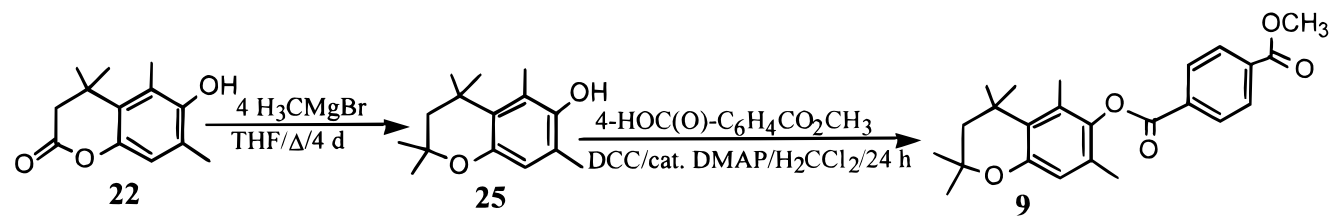

\section{Scheme 4}

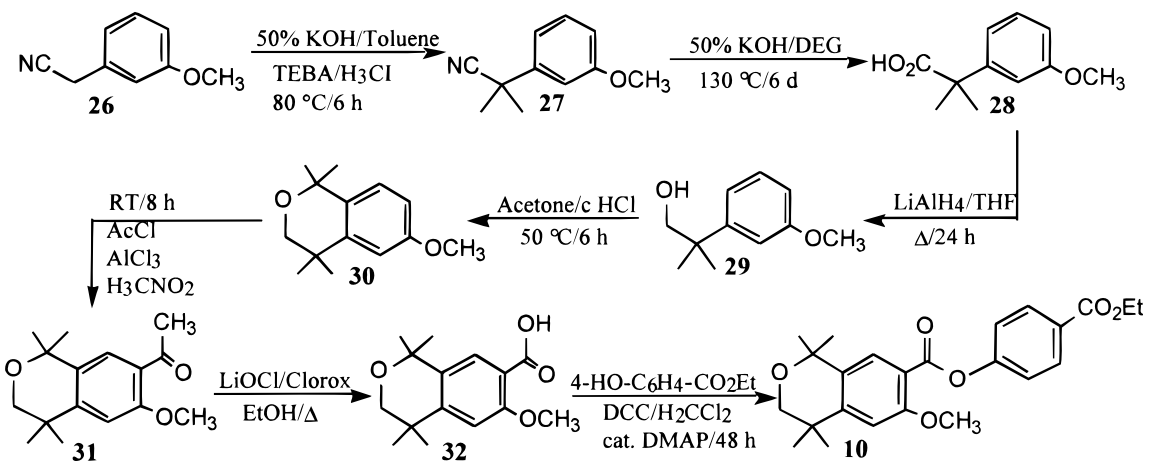

\section{Scheme 5}<smiles>COc1ccc2c(c1)C(C)(C)CCC2(C)C</smiles>

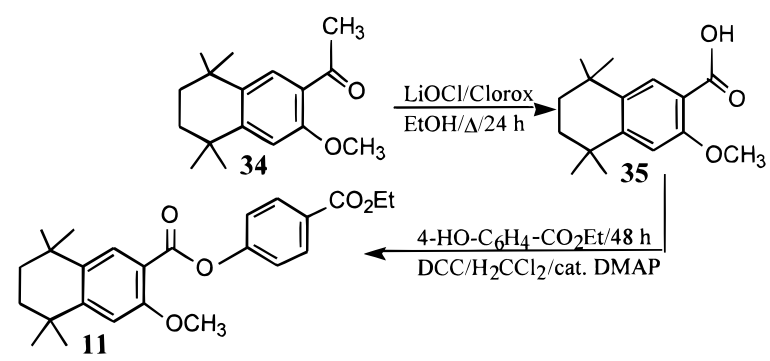

be evaluated because these mice developed very large tumors and died rapidly of disease (data not shown). Mice injected with SCC-38, however, developed stable tumors and survived the duration of the month-long experiment. Mice bearing SCC-38 xenografts were arbitrarily divided into 4 treatment groups of 5 mice each and were gavaged with $0.1 \mathrm{~mL}$ of sesame oil containing either 20 mg/kg/day of t-RA (1), $10 \mathrm{mg} / \mathrm{kg} /$ day of $\mathbf{6}, 10 \mathrm{mg} / \mathrm{kg} /$ day of $\mathbf{1 6}$, or no drug control. After 1 week of treatment, the dose of t-RA (1) was decreased to $10 \mathrm{mg} / \mathrm{kg} / \mathrm{day}$ due to excessive eczema and bone fractures in this group of mice. These toxicities were not evident in the other three treatment groups. There was no significant difference in the animal weights between the treatment groups (Figure 1, panel A).
Tumors developed from the SCC-38 cell line underwent a reduction in volume during days 9-14, followed by a stabilization of tumor size (Figure 1, panels $B-D$ ). The tumors in the groups treated with t-RA (1) and $\mathbf{1 6}$ stabilized starting on days 12 and 14, respectively, at sizes that were significantly smaller than the tumors in the control group ( $P<0.05$, t-test), which were also stable during this period. The sizes of the tumors in the group treated with $\mathbf{6}$ were not significantly smaller than the tumors of the control group until day 26 ( $P<0.05$, t-test). The last day of tumor measurements demonstrated growth in the control group compared to continued stabilization or further reduction in the treatment groups. The average tumor volumes of the four treatment groups were significantly different from each other after day 23 as determined by ANOVA $(P<0.05)$.

Complete tumor regression was observed in 3 of 5 mice treated with t-RA (1), 4 of 5 mice treated with 16, and 1 of 5 mice treated with $\mathbf{6}$. In the control group, 1 of 5 sesame oil-treated mice had complete tumor regression.

3. Receptor Expression. Retinoids regulate gene expression through two classes of nuclear retinoic acid receptors, RAR and RXR, each of which have three isoforms labeled $\alpha, \beta$, and $\gamma{ }^{9}$ The expression patterns of retinoic acid receptors in SCC-2 and SCC-38 were evaluated by reverse transcriptase polymerase chain reaction (RT-PCR). Both cell lines expressed RAR $\alpha$, $\mathrm{RXR} \alpha$, and $\mathrm{RXR} \beta$ at similar levels (Figure 2). The intensities of the $\beta$ actin control bands for each cell line were similar, but the intensities of the $\operatorname{RAR} \beta$ and $\operatorname{RAR} \gamma$ 


\section{Scheme 6}

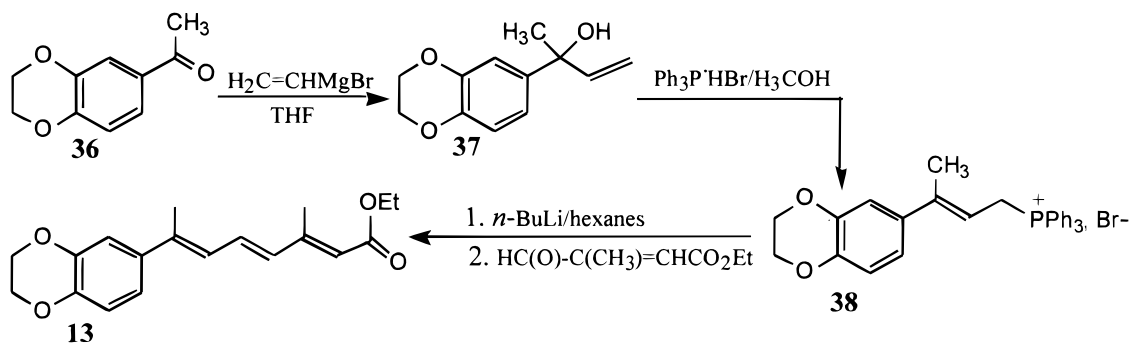

\section{Scheme 7}<smiles>CC1(C)CC(C)(C)c2ccccc2S1</smiles>

$$
\text { (2. NaOH }
$$

Table 1. Percent in Vitro Growth Inhibition of Two HNSCC Cell Lines, SCC-2 and SCC-38, by a 3-Day Exposure to $10 \mu \mathrm{M}$ Heteroarotinoids and 9-c-RA (2)

\begin{tabular}{clrc}
\hline atom & compd & SCC-2 & SCC-38 \\
\hline O & $\mathbf{5}$ & -6 & 13 \\
O & $\mathbf{6}$ & 19 & 18 \\
O & $\mathbf{7}$ & 3 & 17 \\
O & $\mathbf{8}$ & 15 & -8 \\
O & $\mathbf{9}$ & -1 & 9 \\
O & $\mathbf{1 0}$ & 52 & 6 \\
O & $\mathbf{1 2}$ & 1 & 1 \\
O & $\mathbf{1 3}$ & -33 & -2 \\
S & $\mathbf{1 4}$ & 2 & 1 \\
S & $\mathbf{1 5}$ & 10 & 17 \\
S & $\mathbf{1 6}$ & 64 & 37 \\
N & $\mathbf{1 7}$ & 12 & 13 \\
N & $\mathbf{1 8}$ & 9 & 7 \\
N & $\mathbf{1 9}$ & 5 & 15 \\
& $\mathbf{1 1}$ & 15 & 12 \\
& $9-C-R A(\mathbf{2})$ & 13 & 10 \\
\hline
\end{tabular}

bands for each cell line varied, indicating that SCC-2 expressed higher levels of RAR $\beta$ in comparison to SCC38 and that SCC-38 expressed higher levels of RAR $\gamma$ in comparison to SCC-2.

4. Nuclear Retinoid Receptor Activation. While t-RA (1) and arotinoid compounds only activate the RAR receptors, 9-c-RA (2) and some heteroarotinoids activate both RAR and RXR receptors. ${ }^{9}$ To determine the specificity of retinoic acid receptor activation by $\mathbf{6}$ and $\mathbf{1 6}$ cotransfection assays using the RAR $\beta$ RARE-tk-CAT reporter plasmid were performed. All six nucl ear receptors were activated by $\mathbf{6}$ and $\mathbf{1 6}$ in a dose-responsive manner. The concentration that induced half-maximal activity ( $E_{50}$ value) was derived as a measure of receptor potency, and the maximal activity relative to 9-c-RA (2) was derived as a measure of efficacy for each receptor (Table 2). Heteroarotinoid $\mathbf{1 6}$ was a potent activator of all six receptors, while $\mathbf{6}$ was sel ective for the RXR receptors. Although the efficacy of RAR activation by 6 ranged from $24-58 \%$ of the activation by $9-\mathrm{c}-$ RA (2), the greater than $10000 \mathrm{nM}$ potencies demon- strate that the concentrations needed to achieve this activation were above pharmacologically obtainable levels.

5. Anti-AP-1 Activity. Theligand-bound retinoic acid receptors have been shown to repress transcriptional activation by AP-1 transcription factors. ${ }^{30,31}$ This antiAP-1 activity has been implicated in the mechanism of growth inhibition. ${ }^{32,33}$ The ability of t-RA (1), 9-c-RA (2), $\mathbf{6}$, and $\mathbf{1 6}$ to repress AP-1-driven transcription was evaluated using transient transfection assays of an AP1-driven reporter plasmid into SCC-2 cultures (Figure 3). All the retinoids repressed AP-1 activity, and $\mathbf{1 6}$ exhibited the greatest repression. Similar experiments using SCC-38 cultures could not be performed due to the poor transfection efficiency of this line.

\section{Conclusions}

In this report, the potential of certain heteroarotinoids for chemoprevention of head and neck cancers was confirmed by growth inhibition of HNSCC cell lines in vitro and prevention of tumor establishment in a xenograph nude mouse model in vivo. The SCC-38 xenograph tumors in this study exhibited a reduction during days $9-14$, followed by a stabilization of tumor size (Figure 1). The curves in all four groups were remarkably similar for days $9-14$, suggesting that this initial regression in size was due to factors intrinsic to the xenograph model such as absorption of diluent and nonviable tumor cells and resolution of the host's inflammatory response to tumor injection. The last tumor measurement in the control group, however, demonstrated significant growth compared to continued stabilization or further reduction in the treatment groups. This implies that the model is reflective of tumor establishment rather than tumor growth. Establishment of tumor implants appears to have occurred over the initial 28 days following injection, while growth of the established tumors did not occur until after day 28. The efficacy of the two heteroarotinoids in prevention of the establishment of SCC-38 xenograph tumors is indicated by the significant decrease in size of the tumors in the groups treated with 6 and 16. The complete regression of 4 out of 5 xenograph tumors in the group treated with $\mathbf{1 6}$, in comparison to 1 out of 5 in the control group, is a more convincing demonstration of heteroarotinoid chemoprevention activity.

The molecular mechanism of this growth inhibition most likely involves the regulation of gene expression through the nuclear retinoic acid receptors. In support of this hypothesis, the use of t-RA (1) to treat squamous cell carcinoma HNSCC cell lines resulted in decreased expression of two genes that are associated with increased proliferation and that are commonly overex- 
A
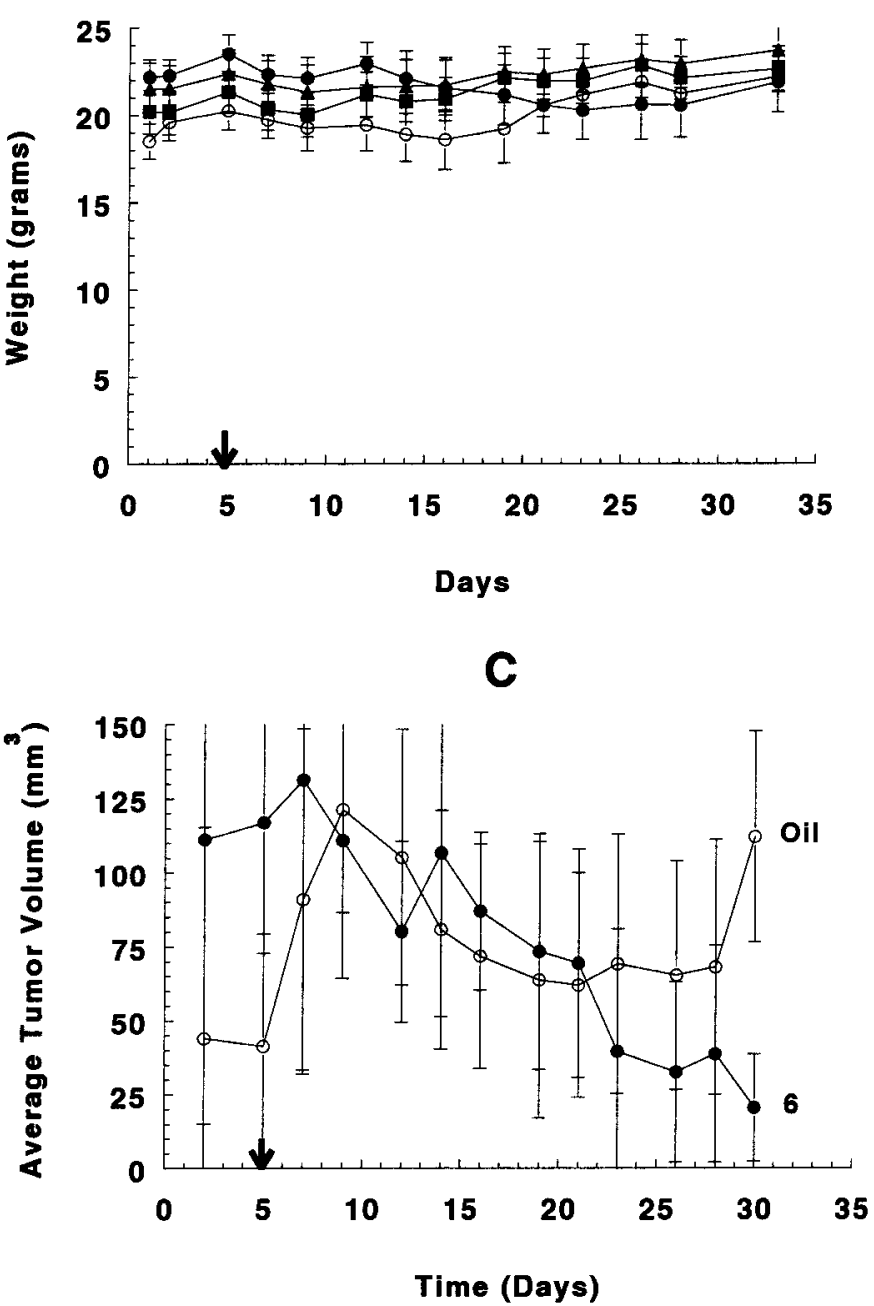

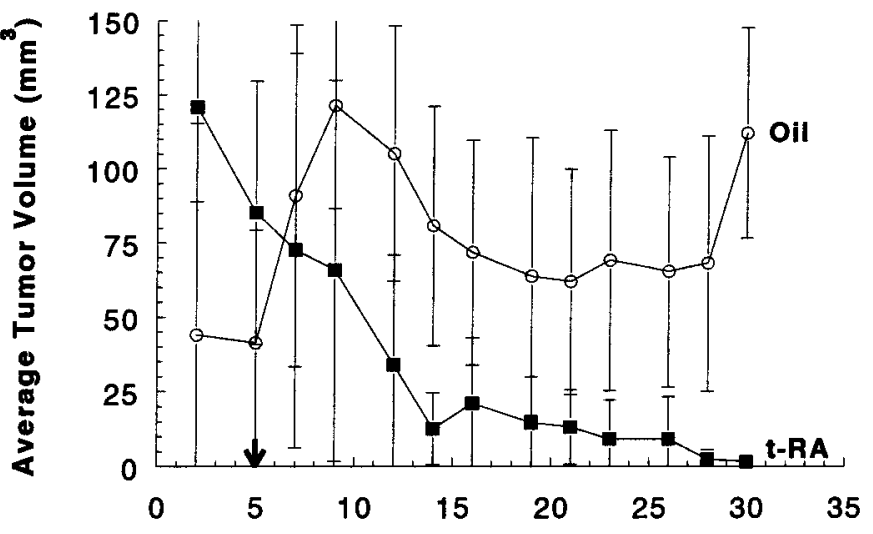

Time (Days)

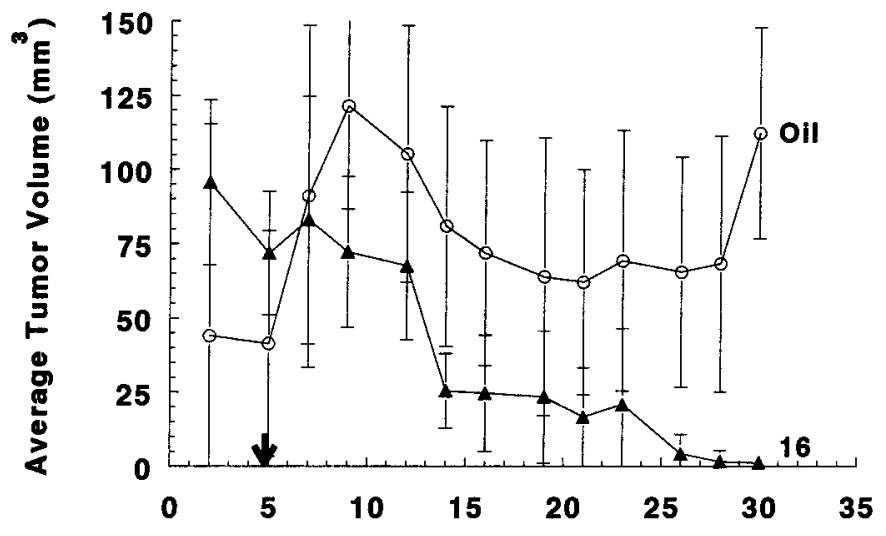

Time (Days)

Figure 1. Xenograft model of retinoid-induced tumor shrinkage. An amount of $10^{7} \mathrm{SCC}-38$ cells was injected into the flanks of 18 nude mice. Five days later, $10 \mathrm{mg} / \mathrm{kg}$ of t-RA (1) $(\mathbf{\square}), \mathbf{6}(\mathbf{0}), \mathbf{1 6}(\mathbf{\Lambda})$, or sesame oil (O) was administered by gavage for 5 consecutive days/week. Each mouse was weighed 3 times/week, and the average weights for each group are shown in panel A. Tumor volumes were measured with calipers. The data in panels B-D represent the average and standard deviations of tumor sizes of 6 mice/ group treated with t-RA (1), 6, or 16, respectively. Retinoid treatment caused a statistically significant decrease in tumor size starting at day 12 for t-RA ( $P=0.025)$, day 26 for $6(P=0.051)$, and day 14 for $16(P=0.016)$ as determined by the Student T-test.

pressed in head and neck cancers, namely the transforming growth factor $\alpha$ (TGF- $\alpha$ ) and the epidermal growth factor receptor (EGF-R). ${ }^{34}$ The growth inhibition activities of compounds, such as t-RA (1), that activate all RAR receptors are not likely to be strongly affected by al terations in the pattern of receptor expression. In agreement with this suggestion, a study using a panel of six HNSCC cell lines reveal ed that receptor expression patterns were unrelated to a response to t-RA (1) treatment. ${ }^{21}$ In contrast, the activities of receptorselective retinoids can be affected by the receptor expression patterns in head and neck lesions. An investigation of premalignant, dysplastic, and malignant head and neck cancers found that $\operatorname{RAR} \beta$ expression was suppressed in more than $50 \%$ of all lesions. ${ }^{23}$ However, RAR $\gamma$ expression was not suppressed and has been implicated in squamous differentiation and t-RA response in HNSCC. ${ }^{35,36}$ The role of RAR $\gamma$ in the mechanism of retinoid growth inhibition in HNSCC cell lines has been illustrated by the use of sense and antisense RAR $\gamma$ expression in the SqCC/Y 1 line. ${ }^{36}$ While
t-RA (1) treatment and sense RAR $\gamma$ expression caused growth inhibition, AP-1 repression and decreased expression of EGF-R and of squamous differentiation markers, anti-sense RAR $\gamma$, antagonized these activities. Therefore, the potencies of RAR $\beta$ and RAR $\gamma$ activation by 16 ( $\mathrm{EC}_{50}$ 's of 1004 and $152 \mathrm{nM}$, respectively) are amenable to use against head and neck lesions that have decreased expression of $\operatorname{RAR} \beta$ and consistent expression of functional RAR $\gamma$.

Both SCC-2 and SCC-38 cell lines evaluated in this study expressed all of the human RAR and RXR nuclear retinoic acid receptors and are therefore susceptible to all retinoic acid receptor-selective compounds. The potent growth inhibition activity of $\mathbf{6}$, which is selective for the RXR receptors, suggests that RXR activation is sufficient for growth inhibition of SCC-2 and SCC-38. The greater activity of 16, which is an RAR/RXR panagonist, indicates that RARs also contribute to the mechanism of growth inhibition by heteroarotinoids. Additive and synergistic activity of RAR- and RXRselective retinoids has been noted in other cell lines in 

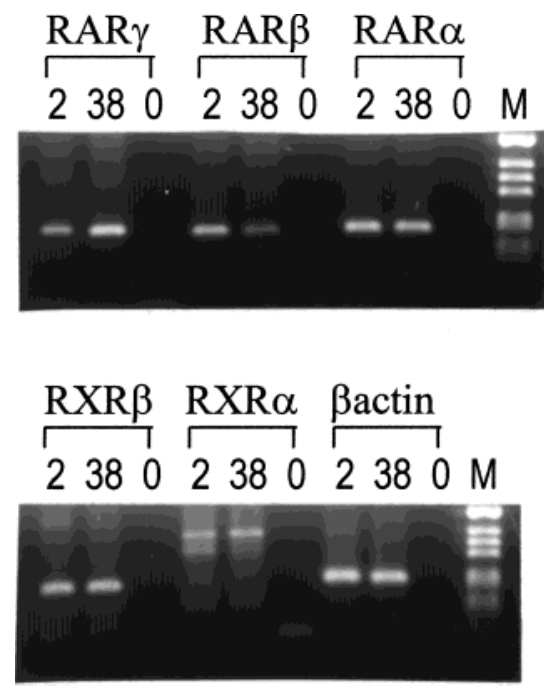

Figure 2. RAR expression profile of SCC-2 and SCC-38. RTPCR reaction products, obtained with primers specific for each receptor, were electrophoresed through 1.5\% agarose gels containing ethidium bromide and photographed. The expected size of the specific bands for $\operatorname{RAR} \alpha, \operatorname{RAR} \beta, \operatorname{RAR} \gamma$, and $\operatorname{RXR} \beta$ is approximately 200 base pairs. The expected size for $R X R \alpha$ is 400 base pairs. The lanes contain RT-PCR reaction products from SCC-2 (2), SCC-38 (38), or no RNA control (0) and molecular weight markers (M) (1 kb DNA ladder, GibcoBRL, Gaithersburg, MD; the top band corresponds to 505 bp's followed by 396, 344, 288, 220, 201, 154, 134, and 75).

vitro. ${ }^{37}$ The inhibition of HNSCC xenograph tumor growth by an RAR-selective retinoid, observed by others, ${ }^{38}$ and by RXR-selective retinoid $\mathbf{6}$, in this study, demonstrates that either RAR or RXR activation is sufficient for growth inhibition. The more potent activity of RAR/RXR pan-agonist $\mathbf{1 6}$ suggests that activation of both RAR and RXR receptors is al so complimentary in vivo.

Since all of the retinoids used in the animal model repressed AP-1-driven transcription to similar extents, the contribution of anti-AP-1 activity to the mechanism of growth inhibition cannot be ruled out. Although the most bi ologically active heteroarotinoid $\mathbf{1 6}$ exhibited the greatest repression of AP-1 activity, it was also the most active RARE transactivator and, therefore, cannot be used to differentiate the two retinoid activities. It is most likely, however, that both anti-AP-1 and RARE transactivation activities are involved in the mechanism of retinoid growth inhibition to different degrees, depending upon the inner cellular environment. A series of heteroarotinoids are currently being investigated for selected anti-AP-1 activity in the absence of RARE transactivation activity. These types of selective compounds can be used to evaluate the role of AP-1 repression in the mechanism of growth inhibition.

In conclusion, the growth inhibitory activity of RXRselective $\mathbf{6}$ and the more potent growth inhibition activity of RAR/RXR pan-agonist $\mathbf{1 6}$ implicate both RARs and RXRs in the mol ecular mechanism of retinoid growth inhibition of HNSCC cell lines. Both agents exhibit anti-AP1 activity that may contribute to the mechanism of action. Moreover, the chemoprevention activity and lack of toxicity of heteroarotinoids demonstrate their clinical potential in head and neck cancer chemoprevention.

\section{Experimental Section}

Chemical Methods. General. IR spectra were recorded on a Perkin-EImer $2000 \mathrm{FT}$-IR as films or as KBr pellets. GCMS data were obtained from a HP G1800A GCD System GC el ectron ionization detector. FAB MS experiments were performed on a VG ZAB-2SE HRMS unit, while EI MS experiments were accomplished with an HP GC-MS ENGINE model 5989B unit. All ${ }^{1} \mathrm{H}$ and ${ }^{13} \mathrm{C}$ NMR spectra were taken on a Varian Inova $400 \mathrm{MHz}$ or Varian XL-400 M Hz BB spectrometer operating at 399.99 and $100.0 \mathrm{~Hz}$, respectively, and signals were referenced to TMS. Melting points were determined with a Thomas-Hoover melting point apparatus and were uncorrected. Syntheses were executed, unless otherwise indicated, under an atmosphere of $\mathrm{N}_{2}$. Elemental analyses were performed by Galbraith Laboratories, Knoxville, TN, or by Atlantic Microlab, Inc., Norcross, GA. All chromatography was performed with the chromatotron unless otherwise noted and utilized silica gel, pF 254 containing gypsum (EM Science).

Heteroarotinoids $\mathbf{5}^{7} \mathbf{6},{ }^{7} \mathbf{1 2},{ }^{6} \mathbf{1 4},{ }^{6} \mathbf{1 5},{ }^{7} \mathbf{1 7},{ }^{39} \mathbf{1 8},{ }^{39}$ and $\mathbf{1 9}^{39}$ were prepared by known methods. Although the intermediates and final products appeared to be relatively stable in light, precautions were taken to minimize exposure to any light source and to the atmosphere. In the purified state, all materials were stored in the cold and dark for indefinite periods without significant decomposition.

Biological Methods. Cell Lines. The SCC-2 cell line was derived from a patient with T1,N0 well-differentiated squamous cell carcinoma of the mandibular alveolus. The SCC-38 cell line was derived from a patient with a T2,N2a moderately well-differentiated squamous cell carcinoma of the base of the tongue. Cells were maintained in Eagles minimal essential media (MEM) containing Earle's salts and L-glutamine, supplemented with nonessential amino acids, antibiotic-antimycotic, sodium pyruvate, and $10 \%$ fetal bovine serum (FBS) in $95 \%$ air $-5 \% \mathrm{CO}_{2}$. Only lots of $\mathrm{FBS}$ that had negligible quantities of retinoic acid as determined by HPLC $\left(<10^{-8} \mathrm{M}\right)$ were used.

Retinoids. All heteroarotinoids (5-10, 12-19), arotinoid 11, t-RA (1; Sigma Chemical Co., St. Louis, MO), and 9-c-RA (2; Bio-M ol, Plymouth Meeting, PA) were dissolved in dimethyl sulfoxide (DMSO) for in vitro studies or highly refined sesame oil (Croda, Inc., Mill Hall, PA) for in vivo studies, were protected from light, and were stored at $-70^{\circ} \mathrm{C}$. For the tissue culture studies, retinoids were added from 1000X stocks, achieving a final concentration of $0.01 \%$ DMSO in the culture medium. F or the animal studies, the retinoids were dissolved at a concentration equal to the daily dose of $0.1 \mathrm{~mL}$ of sesame oil.

Methyl N-(4-Methoxyoxophenyl)-4,4-dimethyl-3,4-dihydro-2H-benzo[b]pyran-6-ylhydroxamate (7). A mixture of powdered $\mathrm{KOH}(0.022 \mathrm{~g}, 0.38 \mathrm{mmol})$ and DMSO $(1 \mathrm{~mL})$ was stirred for $5 \mathrm{~min}$, and then ester $\mathbf{2 1}(0.090 \mathrm{~g}, 0.25 \mathrm{mmol})$ was added, foll owed by an immediate addition of $\mathrm{H}_{3} \mathrm{C}-\mathrm{I}(0.031 \mathrm{~mL}$, $0.51 \mathrm{mmol}$ ) with stirring. After stirring for $0.5 \mathrm{~h}$, the resulting mixture was poured into $\mathrm{H}_{2} \mathrm{O}(10 \mathrm{~mL})$. Extraction $\left(\mathrm{H}_{2} \mathrm{CCl}_{2}, 3\right.$ $\times 10 \mathrm{~mL}$ ) of the aqueous layer and combining the extracts gave a solution which was washed with water and brine. After drying $\left(\mathrm{MgSO}_{4}\right)$, the solution was evaporated to a colorless solid which was recrystallized (hexanes:EtOAc, 4:1) to give 7 (0.045 g, 48\%): $\mathrm{mp} 104-106^{\circ} \mathrm{C}$; IR $(\mathrm{KBr}) 1722,1670(\mathrm{C}=\mathrm{O})$ $\mathrm{cm}^{-1}$; $1 \mathrm{H} \mathrm{NMR}\left(\mathrm{DCCl}_{3}\right) \delta 1.29\left[\mathrm{~s}, 6 \mathrm{H},\left(\mathrm{H}_{3} \mathrm{C}\right)_{2}\right], 1.83[\mathrm{t}, 2 \mathrm{H}$, J $\left.=5.6 \mathrm{~Hz}, \mathrm{CCH}_{3}\right], 3.71\left[\mathrm{~s}, 3 \mathrm{H}, \mathrm{NOCH}_{3}\right], 3.92\left[\mathrm{~s}, 3 \mathrm{H}, \mathrm{OCH}_{3}\right]$, $4.23\left[\mathrm{t}, 2 \mathrm{H}, \mathrm{J}=5.6 \mathrm{~Hz}, \mathrm{OCH}_{2}\right], 6.77[\mathrm{~d}, 1 \mathrm{H}, \mathrm{Ar}-\mathrm{H}], 7.47$ [dd, $1 \mathrm{H}, \mathrm{Ar}-\mathrm{H}$ ], 7.59 [dd, $2 \mathrm{H}, \mathrm{Ar}-\mathrm{H}$ ], $7.63[\mathrm{~d}, 1 \mathrm{H}, \mathrm{Ar}-\mathrm{H}$ ], 8.04 [dd, $2 \mathrm{H}, \mathrm{Ar}-\mathrm{H}$ ]; ${ }^{13} \mathrm{C}$ N MR $\left(\mathrm{DCCl}_{3}\right) \mathrm{ppm} 30.53\left[\mathrm{ArCCH}_{2}\right], 30.74$ $\left[\left(\mathrm{H}_{3} \mathrm{C}\right)_{2}\right], 37.05\left[\mathrm{ArCCH}_{2}\right], 51.15\left[\mathrm{OCH}_{3}\right], 62.17\left[\mathrm{NOCH}_{3}\right], 63.32$ $\left[\mathrm{ArOCH}_{2}\right], 116.59-156.38[\mathrm{Ar}-\mathrm{C}], 166.38[\mathrm{C}=\mathrm{O}], 167.97[\mathrm{C}=$ O]. Anal. $\left(\mathrm{C}_{21} \mathrm{H}_{23} \mathrm{NO}_{5}\right) \mathrm{C}, \mathrm{H}, \mathrm{N}$.

Methyl 4-[(6-Hydroxy-2,4,4,5,7-pentamethyl-4H-benzo[b]pyran-6-yl)carbonyloxy]benzoate (8). To a cloudy mixture of the chromenol $24(0.150 \mathrm{~g}, 0.688 \mathrm{mmol})$, methyl monoterephthalic acid $(0.161 \mathrm{~g}, 0.894 \mathrm{mmol})$, and $\mathrm{H}_{2} \mathrm{CCl}_{2}(10$ $\mathrm{mL}$ ) were added slowly dicyclohexylcarbodiimide $(0.425 \mathrm{~g}, 2.06$ $\mathrm{mmol}$ ) and a catalytic amount $(7 \mathrm{mg})$ of DMAP. After the resulting cloudy solution was stirred ( $\mathrm{rt}$ ) for $24 \mathrm{~h}$ and filtered, 
Table 2. Potency $\left(\mathrm{EC}_{50}, \mathrm{nM}\right)$ and Efficacy (maximal response relative to 9-c-RA (2)) of Heteroarotinoids ${ }^{\mathrm{a}}$

\begin{tabular}{|c|c|c|c|c|c|c|}
\hline \multirow[b]{3}{*}{ compd } & \multicolumn{6}{|c|}{ potency (efficacy) } \\
\hline & \multicolumn{3}{|c|}{ RAR } & \multicolumn{3}{|c|}{$\mathrm{R} \times \mathrm{R}$} \\
\hline & $\alpha$ & $\beta$ & $\gamma$ & $\alpha$ & $\beta$ & $\gamma$ \\
\hline $\begin{array}{r}6 \\
16\end{array}$ & $\begin{array}{r}>10000(24) \\
225(72)\end{array}$ & $\begin{array}{r}>10000(58) \\
1004(73)\end{array}$ & $\begin{array}{r}>10000(38) \\
152(86)\end{array}$ & $\begin{array}{r}294(35) \\
84(80)\end{array}$ & $\begin{array}{r}1897(46) \\
68(49)\end{array}$ & $\begin{array}{r}42(35) \\
302(43)\end{array}$ \\
\hline
\end{tabular}

a The efficacy was derived by dividing the maximal activity induced by $\mathbf{6}$ or $\mathbf{1 6}$ by the maximal activity induced by 9 -c-RA (2). All compounds exhibited maximal activity at a concentration of $10 \mu \mathrm{M}$. The maximal activity induced by 10 $\mu \mathrm{M}$ 9-c-RA (2) was 4.2-fold induction for $\operatorname{RAR} \alpha, 2.6$-fold for $\operatorname{RAR} \beta, 2.4$-fold for $\operatorname{RAR} \gamma, 3.8$-fold for $\mathrm{RXR} \alpha, 4.0$-fold for $\mathrm{RXR} \beta$, and 3.7-fold for $\mathrm{RXR} \gamma$.

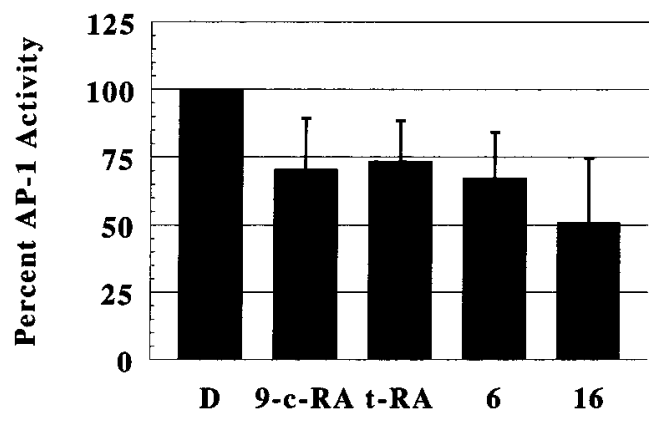

Figure 3. Repression of AP-1-driven transcription. SCC-2 cultures transiently cotransfected with an AP-1 responsive reporter plasmid (ColCAT) and a transfection control plasmid (p) ATL ac) were treated with $10 \mu \mathrm{M}$ of the indicated retinoid. After $48 \mathrm{~h}$ of treatment, cell lysates were prepared and CAT expression was quantitated as a measure of AP-1 activity. The results are presented as the average and standard deviations of 4 determinations.

the filtrate was cooled $\left(0{ }^{\circ} \mathrm{C}\right)$ overnight and filtered again. Evaporation of the solvent gave a heavy oil which was subjected to chromatography $\left(\mathrm{H}_{2} \mathrm{CCl}_{2}\right)$. A white solid $(0.130 \mathrm{~g}$, 50\%) 8 was obtained: $\mathrm{mp} 142-143^{\circ} \mathrm{C}$; IR (KBr) $1736(\mathrm{C}=\mathrm{O})$

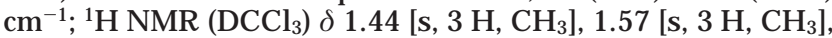
$2.12\left[\mathrm{~s}, 3 \mathrm{H}, \mathrm{Ar}-\mathrm{CH}_{3}\right], 2.27\left[\mathrm{~s}, 3 \mathrm{H}, \mathrm{Ar}-\mathrm{CH}_{3}\right], 3.98[\mathrm{~s}, 3 \mathrm{H}$, $\mathrm{OCH}_{3}$ ] 4.39 [s, $1 \mathrm{H}, \mathrm{C}=\mathrm{CH}$ ], $6.72[\mathrm{~s}, 1 \mathrm{H}, \mathrm{Ar}-\mathrm{H}$ ], 8.18 [dd, 2 $\mathrm{H}, \mathrm{Ar}-\mathrm{H}$ ], 8.30 [dd, $2 \mathrm{H}, \mathrm{Ar}-\mathrm{H}$ ]; ${ }^{13} \mathrm{C} \mathrm{NMR}\left(\mathrm{DCCl}_{3}\right) \mathrm{ppm} 14.88$ $\left[\mathrm{CH}_{3}\right], 16.23\left[\mathrm{CH}_{3}\right], 18.78\left[\mathrm{CH}_{3}\right], 31.79\left[\mathrm{ArCCH}_{2}\right], 32.54\left[\left(\mathrm{H}_{3} \mathrm{C}\right)_{2}\right]$, $52.51\left[\mathrm{OCH}_{3}\right], 109.00-148.51[\mathrm{C}=\mathrm{C}]$ and $[\mathrm{Ar}-\mathrm{C}], 163.83[\mathrm{C}=$ O], $166.13[\mathrm{C}=\mathrm{O}], 168.07[\mathrm{C}=\mathrm{O}]$. Anal. $\left(\mathrm{C}_{23} \mathrm{H}_{24} \mathrm{O}_{5}\right) \mathrm{C}, \mathrm{H}$.

Methyl 4-[(2,2,4,4,5,7-Hexamethyl-3,4-dihydro-2H-benzo[b]pyran-6-yl)carbonyloxy]benzoate (9). To a cloudy mixture of $\mathbf{2 5}(0.085 \mathrm{~g}, 0.366 \mathrm{mmol})$ and methyl monoterephthalic acid $(0.115 \mathrm{~g}, 0.641 \mathrm{mmol})$ in $\mathrm{H}_{2} \mathrm{CCl}_{2}(10 \mathrm{~mL})$ were added dicyclohexylcarbodiimide $(0.132 \mathrm{~g}, 0.641 \mathrm{mmol})$ and a catalytic amount (4 mg) of DMAP. The resulting solution was stirred (18 h) at rt, filtered, and evaporated to a heavy oil which was chromatographed $\left(\mathrm{H}_{2} \mathrm{CCl}_{2}\right)$. The oil crystallized when treated

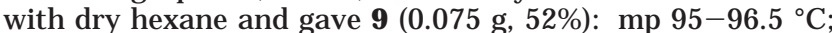
IR (KBr) $1730(\mathrm{C}=\mathrm{O}) \mathrm{cm}^{-1}$; ${ }^{1} \mathrm{H}$ NMR $\left(\mathrm{DCCl}_{3}\right) \delta 1.35[\mathrm{~s}, 6 \mathrm{H}$, $\left.\left(\mathrm{H}_{3} \mathrm{C}\right)_{2}\right], 1.48\left[\mathrm{~s}, 6 \mathrm{H},\left(\mathrm{H}_{3} \mathrm{C}\right)_{2}\right], 1.87\left[\mathrm{~s}, 2 \mathrm{H}, \mathrm{CH}_{2}\right], 2.08[\mathrm{~s}, 3 \mathrm{H}$, $\left.\mathrm{Ar}-\mathrm{CH}_{3}\right], 2.29\left[\mathrm{~s}, 3 \mathrm{H}, \mathrm{Ar}-\mathrm{CH}_{3}\right], 3.98\left[\mathrm{~s}, 3 \mathrm{H}, \mathrm{OCH}_{3}\right], 6.61[\mathrm{~s}$, $1 \mathrm{H}, \mathrm{Ar}-\mathrm{H}], 8.18[\mathrm{~d}, 2 \mathrm{H}, \mathrm{Ar}-\mathrm{H}], 8.29[\mathrm{~d}, 2 \mathrm{H}, \mathrm{Ar}-\mathrm{H}] ;{ }^{13} \mathrm{C}$ NMR $\left(\mathrm{DCCl}_{3}\right) \mathrm{ppm}$ 15.17 $\left[\mathrm{Ar}-\mathrm{CH}_{3}\right], 16.24\left[\mathrm{Ar}-\mathrm{CH}_{3}\right], 27.87$ $\left[\left(\mathrm{H}_{3} \mathrm{C}\right)_{2}\right], 30.78\left[\left(\mathrm{H}_{3} \mathrm{C}\right)_{2}\right], 32.13\left[\mathrm{Ar}-\mathrm{C}\left(\mathrm{CH}_{3}\right)_{2}\right], 52.51\left[\mathrm{OCH}_{3}\right]$, $53.33\left[\mathrm{ArOC}\left(\mathrm{CH}_{3}\right)_{2}\right], 73.11\left[\mathrm{OC}\left(\mathrm{CH}_{3}\right)_{2}\right], 118.09-150.80[\mathrm{Ar}-$ $\mathrm{C}], 163.97[\mathrm{C}=\mathrm{O}], 166.19[\mathrm{C}=\mathrm{O}]$. Anal. $\left(\mathrm{C}_{24} \mathrm{H}_{28} \mathrm{O}_{5}\right) \mathrm{C}, \mathrm{H}$.

Ethyl 4-[(1,1,4,4-Tetramethyl-7-methoxy-3,4-dihydro1H-2-benzo[b]pyran-6-yl)carbonyloxy]benzoate (10). To a cloudy mixture of acid $32(0.100 \mathrm{~g}, 0.382 \mathrm{mmol})$ and ethyl 4-hydroxybenzoate $(0.095 \mathrm{~g}, 0.573 \mathrm{mmol})$ were added dicyclohexylcarbodiimide $(0.118 \mathrm{~g}, 0.573 \mathrm{mmol})$ and a catalytic amount of DMAP $(7 \mathrm{mg})$. The yellow solution was stirred at $\mathrm{rt}(48 \mathrm{~h})$ and then filtered. Evaporation of the solution gave a heavy oil which was chromatographed (hexane:EtOAc, 3:1). An oil resulted and was treated with $0.5 \mathrm{~mL}$ of hexane:EtOAc (4:1) and chilled. Crystallization occurred to give solid $\mathbf{1 0}$ (0.110 g, 70\%): mp 106.5-108 ${ }^{\circ} \mathrm{C}$; IR $1722(\mathrm{C}=\mathrm{O}) \mathrm{cm}^{-1}$; ${ }^{1} \mathrm{H}$ $\operatorname{NMR}\left(\mathrm{DCCl}_{3}\right) \delta 1.32\left[\mathrm{~s}, 6 \mathrm{H},\left(\mathrm{H}_{3} \mathrm{C}\right)_{2}\right], 1.40[\mathrm{~s}, 3 \mathrm{H}, \mathrm{J}=7.2 \mathrm{~Hz}$, $\left.\mathrm{CH}_{3}\right], 1.56\left[\mathrm{~s}, 6 \mathrm{H},\left(\mathrm{H}_{3} \mathrm{C}\right)_{2}\right], 3.62\left[\mathrm{~s}, 2 \mathrm{H}, \mathrm{H}_{2} \mathrm{CO}\right], 3.94[\mathrm{~s}, 3 \mathrm{H}$,
$\left.\mathrm{OCH}_{3}\right], 4.40\left[\mathrm{q}, 2 \mathrm{H}, \mathrm{J}=7.2 \mathrm{~Hz}, \mathrm{OCH}_{2}\right], 6.93[\mathrm{~s}, 1 \mathrm{H}, \mathrm{Ar}-\mathrm{H}$ ], 7.29 [d, $2 \mathrm{H}, \mathrm{Ar}-\mathrm{H}$ ], 7.73 [s, $1 \mathrm{H}, \mathrm{Ar}-\mathrm{H}$ ], 8.12 [s, $2 \mathrm{H}, \mathrm{Ar}-\mathrm{H}$ ]; ${ }^{13} \mathrm{C} \mathrm{NMR}\left(\mathrm{DCCl}_{3}\right) \mathrm{ppm} 14.31\left[\mathrm{H}_{2} \mathrm{C}-\mathrm{CH}_{3}\right], 26.79\left[\left(\mathrm{H}_{3} \mathrm{C}\right)_{2}\right], 29.76$ $\left[\left(\mathrm{H}_{3} \mathrm{C}\right)_{2}\right], 34.67\left[\mathrm{ArC}\left(\mathrm{CH}_{3}\right)_{2}\right], 56.11\left[\mathrm{ArCOCH}_{2}\right], 61.03\left[\mathrm{CH}_{2}-\right.$ $\mathrm{CH}_{3}$ ], 70.33[ArOCH $\left.\mathrm{AH}_{3}\right], 74.86\left[\mathrm{H}_{2} \mathrm{CO}\right], 108.79-158.29[\mathrm{Ar}-\mathrm{C}]$, 163.59, $165.93[\mathrm{C}=\mathrm{O}]$. Anal. $\left(\mathrm{C}_{24} \mathrm{H}_{28} \mathrm{O}_{6}\right) \mathrm{C}, \mathrm{H}$

Ethyl 4-[(3-Methoxy-5,6,7,8-tetrahydro-5,5,8,8-tetramethylnaphthalen-2-yl)carbonyloxy]benzoate (11). To a cloudy mixture of acid $35(0.300 \mathrm{~g}, 1.14 \mathrm{mmol})$ and ethyl 4-hydroxybenzoate $(0.300 \mathrm{~g}, 1.8 \mathrm{mmol})$ were added dicyclohexylcarbodiimi de $(0.750 \mathrm{~g}, 3.6 \mathrm{mmol})$ and a catalytic amount of DMAP (10 mg). After the resulting clear solution had been stirred at rt ( $24 \mathrm{~h})$ and then filtered, it was evaporated to a heavy oil. Chromatography of the oil (hexane:EtOAc, 4:1) gave ester $11(0.312 \mathrm{~g}, 67 \%)$ as a white solid: $\mathrm{mp} 104-106{ }^{\circ} \mathrm{C}$; IR $(\mathrm{KBr}) 1722(\mathrm{C}=\mathrm{O}) \mathrm{cm}^{-1} ;{ }^{1} \mathrm{H}$ NMR $\left(\mathrm{DCCl}_{3}\right) \delta 1.28[\mathrm{~s}, 6 \mathrm{H}$, $\left.\left(\mathrm{H}_{3} \mathrm{C}\right)_{2}\right], 1.30\left[\mathrm{~s}, 6 \mathrm{H},\left(\mathrm{H}_{3} \mathrm{C}\right)_{2}\right], 1.39\left[\mathrm{t}, 3 \mathrm{H}, \mathrm{J}=7.2 \mathrm{~Hz}, \mathrm{CH}_{2} \mathrm{CH}_{3}\right]$, $1.68\left[2 \mathrm{t}, 4 \mathrm{H}, \mathrm{J}=6.0 \mathrm{~Hz},\left(\mathrm{CH}_{2}\right)_{2}\right], 3.89\left[\mathrm{~s}, 3 \mathrm{H}, \mathrm{OCH}_{3}\right], 4.37[\mathrm{q}$, $\left.2 \mathrm{H}, \mathrm{J}=7.2 \mathrm{~Hz}, \mathrm{CH}_{2} \mathrm{CH}_{3}\right], 6.90[\mathrm{~s}, 1 \mathrm{H}, \mathrm{Ar}-\mathrm{H}], 7.26[\mathrm{~d}, 2 \mathrm{H}$, $\mathrm{Ar}-\mathrm{H}], 7.93[\mathrm{~s}, 1 \mathrm{H}, \mathrm{Ar}-\mathrm{H}], 8.07[\mathrm{~d}, 2 \mathrm{H}, \mathrm{Ar}-\mathrm{H}] ;{ }^{13} \mathrm{C} \mathrm{NMR}$ $\left(\mathrm{DCCl}_{3}\right) \mathrm{ppm} 14.34\left[\mathrm{CH}_{2} \mathrm{CH}_{3}\right], 31.65\left[\left(\mathrm{H}_{3} \mathrm{C}\right)_{2}\right], 31.86\left[\left(\mathrm{H}_{3} \mathrm{C}\right)_{2}\right]$, $33.75\left[\mathrm{CH}_{2}\right], 34.82\left[\mathrm{CH}_{2}\right], 34.84\left[\mathrm{ArC}\left(\mathrm{CH}_{3}\right)_{2}\right], 35.09\left[\mathrm{ArC}\left(\mathrm{CH}_{3}\right)_{2}\right]$, $56.07\left[\mathrm{OCH}_{3}\right], 61.03\left[\mathrm{CH}_{2} \mathrm{CH}_{3}\right], 110.07-157.71[\mathrm{Ar}-\mathrm{C}], 163.85$ $[\mathrm{C}=\mathrm{O}], 166.03[\mathrm{C}=\mathrm{O}]$. Anal. $\left(\mathrm{C}_{22} \mathrm{H}_{23} \mathrm{NO}_{5}\right) \mathrm{C}, \mathrm{H}$.

Ethyl (2E ,4E ,6E )-7-(2,3-Dihydro-1,4-benzodioxan-6-yl)3-methyl-2,4,6-octatrienoate (13). To a stirred suspenion of $38(4 \mathrm{~g}, 7.53 \mathrm{mmol})$ in dry ether $(40 \mathrm{~mL})$ was added dropwise n-BuLi (14 mL, $0.906 \mathrm{M}, 21.7 \mathrm{mmol}$ in hexanes) over $5 \mathrm{~min}$. The resulting dark red solution was stirred for $0.5 \mathrm{~h}$, and then ethyl 3-methyl-4-oxocrotonate $(1.3 \mathrm{~mL}, 9.15 \mathrm{mmol})$ in dry ether $(10 \mathrm{~mL})$ was added dropwise. After $10 \mathrm{~h}$ of stirring at $\mathrm{rt}$, the solution was diluted (hexanes, $100 \mathrm{~mL}$ ), filtered, and evaporated to a light yellow oil. Crystals formed upon standing and were recrystallized (absolute ethanol) to give $13(0.683 \mathrm{~g}$, 28.85\%): $\mathrm{mp} \mathrm{86}-87^{\circ} \mathrm{C}$; IR $1690(\mathrm{C}=\mathrm{O}) \mathrm{cm}^{-1}$; ${ }^{1} \mathrm{H}$ NMR $\left(\mathrm{DCCl}_{3}\right)$ $\delta 1.3[\mathrm{t}, \mathrm{J}=7.1 \mathrm{~Hz}, 3 \mathrm{H}, \mathrm{H}(19)], 2.20[\mathrm{~s}, 3 \mathrm{H}, \mathrm{H}(10)], 2.37$ [d, $\mathrm{J}=0.98 \mathrm{~Hz}, 3 \mathrm{H}, \mathrm{H}(15)], 4.17[\mathrm{q}, \mathrm{J}=7.1 \mathrm{~Hz}, 2 \mathrm{H}, \mathrm{H}(18)], 4.27$ $[\mathrm{s}, 4 \mathrm{H}, \mathrm{H}(2,3)], 5.78[\mathrm{bs}, 1 \mathrm{H}, \mathrm{H}(16)], 6.33[\mathrm{~d}, \mathrm{~J}=15.1 \mathrm{~Hz}, 1$ $\mathrm{H}, \mathrm{H}(13)], 6.51[\mathrm{~d}, \mathrm{~J}=11.2 \mathrm{~Hz}, \mathrm{H}(11)], 6.87-7.04[\mathrm{~m}, 3 \mathrm{H}$, $\mathrm{H}(5,7,8)]$. Anal. $\left(\mathrm{C}_{16} \mathrm{H}_{22} \mathrm{O}_{4}\right) \mathrm{C}, \mathrm{H}$

Methyl 4-[(2,3-Dihydro-2,2,4,4-tetramethyl-2H-1-benzothiopyran-6-yl)carbamoyl]benzoate (16). To a solution of amine 41 (1.6 g, $7.32 \mathrm{mmol})$ in dry benzene $(90 \mathrm{~mL})$ and pyridine $(9.2 \mathrm{~mL})$ at rt was added slowly, with stirring, freshly made methyl monoterephthal oyl chloride $(2.20 \mathrm{~g}, 10.84 \mathrm{mmol})$. After stirring for $12 \mathrm{~h}$ (rt), the mixture was poured into water, and the resulting mixture was extracted (EtOAc, $4 \times 200 \mathrm{~mL}$ ). The combined extracts were washed with $6 \mathrm{~N} \mathrm{HCl}(4 \times 50$ $\mathrm{mL}), \mathrm{H}_{2} \mathrm{O}(3 \times 400 \mathrm{~mL})$, saturated $\mathrm{NaHCO}_{3}(2 \times 400 \mathrm{~mL})$, $\mathrm{H}_{2} \mathrm{O}(50 \mathrm{~mL})$, and brine $(200 \mathrm{~mL})$. The dried $\left(\mathrm{Na}_{2} \mathrm{SO}_{4}\right)$ organic solution was evaporated to a light yellow solid which was purified via chromatography over silica gel (hexane:EtOAc: $\mathrm{Et}_{2} \mathrm{NH}, 74: 25: 1$ ). Recrystallization (hexane:EtOAc, 3:1) of the solid gave 16 (2.00 g, 72\%): $\mathrm{mp} 154-155{ }^{\circ} \mathrm{C}$; a further recrystallized analytical sample of 16 melted at $162-164{ }^{\circ} \mathrm{C}$; IR (KBr) 3395-3390 (N-H), $1725(\mathrm{C}=\mathrm{O}), 1690-1680(\mathrm{HNC}=$ O) $\mathrm{cm}^{-1} ;{ }^{1} \mathrm{H} N M R\left(\mathrm{DCCl}_{3}\right) \delta 1.41\left[\mathrm{~s}, 6 \mathrm{H},\left(\mathrm{H}_{3} \mathrm{C}\right)_{2}\right], 1.42[\mathrm{~s}, 6 \mathrm{H}$, $\left.\mathrm{SC}\left(\mathrm{CH}_{3}\right)_{2}\right], 1.96\left[\mathrm{~s}, 2 \mathrm{H}, \mathrm{CH}_{2}\right], 3.95\left[\mathrm{~s}, 3 \mathrm{H}, \mathrm{CH}_{3}\right], 7.11[\mathrm{~d}, 1 \mathrm{H}$, $\mathrm{Ar}-\mathrm{H}], 7.33[\mathrm{~d}, 1 \mathrm{H}, \mathrm{Ar}-\mathrm{H}], 7.76[\mathrm{~s}, 1 \mathrm{H}, \mathrm{Ar}-\mathrm{H}], 7.91[\mathrm{~d}, 2 \mathrm{H}$, $\mathrm{Ar}-\mathrm{H}$ ], 7.93 [bs, $1 \mathrm{H}, \mathrm{Ar}-\mathrm{H}$ ], $8.12[\mathrm{~d}, 2 \mathrm{H}, \mathrm{Ar}-\mathrm{H}$ ], 8.13 [s, 1 $\mathrm{H}, \mathrm{Ar}-\mathrm{H}] ;{ }^{13} \mathrm{C} \mathrm{NMR}\left(\mathrm{DCCl}_{3}\right) \mathrm{ppm} 31.51\left[\mathrm{C}\left(\mathrm{CH}_{3}\right)\right], 32.48[\mathrm{SC}-$ $\left.\left(\mathrm{CH}_{3}\right)_{2}\right], 35.94\left[\mathrm{CCH}_{3}\right], 42.17\left[\mathrm{SC}\left(\mathrm{CH}_{3}\right)_{2}\right], 52.43\left[\mathrm{CH}_{2}\right], 54.33$ $\left[\mathrm{OCH}_{3}\right], 118.61-143.66[\mathrm{Ar}-\mathrm{C}], 164.72[\mathrm{NHC}=\mathrm{O}], 166.21$ 
[HOC=O]; MS (EI) calcd for $\mathrm{C}_{22} \mathrm{H}_{25} \mathrm{O}_{3} \mathrm{SN}\left[\mathrm{M}^{+}\right]$383.1555, found 381.1552. Anal. $\left(\mathrm{C}_{22} \mathrm{H}_{25} \mathrm{O}_{3} \mathrm{SN}\right) \mathrm{C}, \mathrm{H}, \mathrm{N}$.

N-(4-Methoxyoxophenyl)-4,4-dimethyl-3,4-dihydro-2Hbenzo[b]pyran-6-ylhydroxamic Acid (21). Acid $\mathbf{2 0}^{7}$ (0.300 $\mathrm{g}, 1.40 \mathrm{mmol}$ ) and thionyl chloride ( $15 \mathrm{~mL}$ ) were stirred at $\mathrm{rt}$ for $16 \mathrm{~h}$. Excess thionyl chloride was evaporated under aspirator pressure, and the residual acid choride (an oil) was further dried under higher vacuum $(\sim 2 \mathrm{mmHg})$ to remove traces of thionyl chloride. The hydroxylamine $(0.253 \mathrm{~g}, 1.40$ $\mathrm{mmol})$ was dissolved in THF $(10 \mathrm{~mL})$, and then $\mathrm{NaHCO}_{3}(0.176$ g, $2.1 \mathrm{mmol}$ ) was added at rt. The above acid chloride was dissolved in a minimum of dry ether and then was added slowly to the solution of the hydroxylamine at $0{ }^{\circ} \mathrm{C}$. The resulting mixture was stirred (rt) for $18 \mathrm{~h}$, filtered, and evaporated in vacuo to yield a solid. Chromatography of the solid (hexanes:EtOAc, 1:10) gave $\mathbf{2 1}(0.250 \mathrm{~g}, 50 \%)$ : mp 70$71^{\circ} \mathrm{C}$; IR (KBr) $3428(\mathrm{O}-\mathrm{H}), 1721,1634(\mathrm{C}=\mathrm{O}) \mathrm{cm}^{-1}$; ${ }^{1} \mathrm{H}$ NMR $\left.\left(\mathrm{DCCl}_{3}\right) \delta 1.13\left[\mathrm{~s}, 6 \mathrm{H},\left(\mathrm{CH}_{3}\right)_{2}\right], 1.78\left[\mathrm{t}, 2 \mathrm{H}, \mathrm{J}=5.6 \mathrm{~Hz}, \mathrm{CCH}_{2}\right)\right]$ $3.90\left[\mathrm{~s}, 3 \mathrm{H}, \mathrm{OCH}_{3}\right], 4.19\left[\mathrm{t}, 2 \mathrm{H}\right.$, J $\left.=5.6 \mathrm{~Hz}, \mathrm{H}_{2} \mathrm{CO}\right], 6.68[\mathrm{~d}$, $2 \mathrm{H}, \mathrm{Ar}-\mathrm{H}$ ], 7.20 [dd, $1 \mathrm{H}, \mathrm{Ar}-\mathrm{H}$ ], 7.25 [dd, $1 \mathrm{H}, \mathrm{Ar}-\mathrm{H}$ ], 7.34 [d, $1 \mathrm{H}, \mathrm{Ar}-\mathrm{H}], 7.96[\mathrm{~d}, 2 \mathrm{H}, \mathrm{Ar}-\mathrm{H}], 9.18[\mathrm{~s}, 1 \mathrm{H}, \mathrm{OH}]$. Anal. $\left(\mathrm{C}_{20} \mathrm{H}_{21} \mathrm{NO}_{5}\right) \mathrm{C}, \mathrm{H}$. Acid 21 was used at once to obtain $\mathbf{7}$.

2,3-Dihydro-2,6-di hydroxy-2,4,4,5,7-pentamethyl-2Hbenzopyran (23). To a solution of $1.50 \mathrm{~mL}(4.50 \mathrm{mmol})$ of 3 $M$ methylmagnesium bromide in ether $(5 \mathrm{~mL})$ was added $(\mathrm{rt})$ the coumarol $22^{27}(0.100 \mathrm{~g}, 0.45 \mathrm{mmol})$ in ether $(5 \mathrm{~mL})$. The resulting solution was stirred for $48 \mathrm{~h}(\mathrm{rt})$. After the solution was allowed to cool to $\mathrm{rt}$, a saturated solution $(\sim 10 \mathrm{~mL})$ of aqueous $\mathrm{H}_{4} \mathrm{NCl}$ was added slowly. Separation of the layers was followed by extraction (ether, $3 \times 10 \mathrm{~mL}$ ) of the organic layer to give extracts which were washed with water and brine. After drying $\left(\mathrm{MgSO}_{4}\right)$, the sol ution was evaporated to give the lactol 23 as a colorless solid $(0.57 \mathrm{~g}, 54 \%)$ : $\mathrm{mp} 105.5-106.5^{\circ} \mathrm{C}$; IR $(\mathrm{KBr}) 3472,3408(\mathrm{O}-\mathrm{H}) \mathrm{cm}^{-1} ;{ }^{1} \mathrm{H} \mathrm{NMR}\left(\mathrm{DCCl}_{3}\right) \delta 1.41[\mathrm{~s}, 3$ $\left.\mathrm{H}, \mathrm{CCH}_{3}\right], 1.58\left[\mathrm{~s}, 3 \mathrm{H}, \mathrm{CCH}_{3}\right], 1.62\left[\mathrm{~s}, 3 \mathrm{H}, \mathrm{C}(\mathrm{OH})-\mathrm{CH}_{3}\right], 1.90$ [d, $1 \mathrm{H}, \mathrm{J}=14 \mathrm{~Hz}, \mathrm{CH}_{2}$ ], $1.99\left[\mathrm{~d}, 1 \mathrm{H}\right.$, J $=14 \mathrm{~Hz}, \mathrm{CH}_{2}$ ], 2.18 $\left[\mathrm{s}, 3 \mathrm{H}, \mathrm{Ar}-\mathrm{CH}_{3}\right], 2.38\left[\mathrm{~s}, 3 \mathrm{H}, \mathrm{Ar}-\mathrm{CH}_{3}\right], 4.31[\mathrm{~s}, 1 \mathrm{H}, \mathrm{OH}]$, $6.52[\mathrm{~s}, 1 \mathrm{H}, \mathrm{Ar}-\mathrm{H}] ;{ }^{13} \mathrm{C} N M R\left(\mathrm{DCCl}_{3}\right) \mathrm{ppm} 14.75\left[\mathrm{Ar}-\mathrm{CH}_{3}\right]$, $15.86\left[\mathrm{Ar}-\mathrm{CH}_{3}\right], 28.92\left[\left(\mathrm{H}_{3} \mathrm{C}\right)_{2}\right], 29.95\left[\left(\mathrm{H}_{3} \mathrm{C}\right)_{2}\right], 30.93\left[\mathrm{CH}_{2}\right]$,

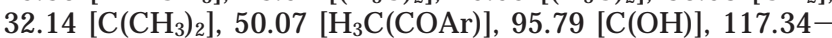
147.25 [Ar-C]. MS (EI) calcd for $\mathrm{C}_{14} \mathrm{H}_{20} \mathrm{O}_{3}\left[\mathrm{M}^{+}\right]$236, found 236. Lactol 23 was converted to 24

6-Hydroxy-2,4,4,5,7-pentamethyl-4H-1-benzopyran (24). A mixture of lactol $23(0.100 \mathrm{~g}, 0.42 \mathrm{mmol})$, a catalytic amount of $p$-toluenesulfonic acid $(0.025 \mathrm{~g}), 4 \mathrm{~A}$ molecular sieves (1.0 $\mathrm{g}$ ), and toluene was boiled for $2 \mathrm{~h}$. After cooling to $\mathrm{rt}$ and filtering, the filtrate was washed with a saturated solution of $\mathrm{NaHCO}_{3}(\sim 10 \mathrm{~mL})$ and then with brine. The dried $\left(\mathrm{Na}_{2} \mathrm{SO}_{4}\right)$ organic solution was evaporated to yield $\mathbf{2 4}(0.082 \mathrm{~g}, 89 \%)$ as a light yellow oil: IR (neat) $3576(\mathrm{O}-\mathrm{H}) \mathrm{cm}^{-1}$; ${ }^{1} \mathrm{H} \mathrm{NMR}\left(\mathrm{DCCl}_{3}\right)$ $\left.\delta 1.43\left[\mathrm{~s}, 6 \mathrm{H},\left(\mathrm{H}_{3} \mathrm{C}\right)_{2}\right)\right], 1.85\left[\mathrm{~s}, 3 \mathrm{H}, \mathrm{C}=\mathrm{C}-\mathrm{CH}_{3}\right], 2.19[\mathrm{~s}, 3 \mathrm{H}$, $\left.\mathrm{Ar}-\mathrm{CH}_{3}\right], 2.33\left[\mathrm{~s}, 3 \mathrm{H}, \mathrm{Ar}-\mathrm{CH}_{3}\right], 4.33[\mathrm{~s}, 1 \mathrm{H}, \mathrm{OH}], 4.39[\mathrm{~s}, 1$ $\left.\mathrm{H}, \mathrm{C}=\mathrm{CH}_{2}\right], 6.60[\mathrm{~s}, 1 \mathrm{H}, \mathrm{Ar}-\mathrm{H}] ;{ }^{13} \mathrm{C} \mathrm{NMR}\left(\mathrm{DCCl}_{3}\right) \mathrm{ppm} 14.38$ $\left[\mathrm{Ar}-\mathrm{CH}_{3}\right], 15.79\left[\mathrm{Ar}-\mathrm{CH}_{3}\right], 18.87\left[\mathrm{C}=\mathrm{CCH}_{2}\right], 31.82\left[\left(\mathrm{H}_{3} \mathrm{C}\right)_{2}\right]$, $32.42\left[\mathrm{C}\left(\mathrm{CH}_{3}\right)_{2}\right], 108.74[\mathrm{C}=\mathrm{CH}], 116.12\left[\mathrm{C}=\mathrm{CCH}_{3}\right], 121.91-$ 148-30 [Ar-C]; MS (EI) calcd for $\mathrm{C}_{14} \mathrm{H}_{18} \mathrm{O}_{2}\left[\mathrm{M}^{+}\right] 218$, found 218. This chromenol $\mathbf{2 4}$ was used directly to prepare heteroarotinoid 8.

2,2,4,4,5,7-Hexamethyl-6-hydroxy-3,4-dihydro-2H-benzo[b]pyran (25). To a solution of methylmagnesium bromide $(1.50 \mathrm{~mL}, 34.50 \mathrm{mmol}, 3 \mathrm{M})$ in THF $(5 \mathrm{~mL})$ was added coumarol $22^{27}(0.100 \mathrm{~g}, 0.45 \mathrm{mmol})$ in THF $(5 \mathrm{~mL})$ at rt. The resulting solution was stirred for 4 days at reflux and was then all owed to cool. Saturated aqueous $\mathrm{H}_{4} \mathrm{NCl}$ was added, and two layers separated. Extraction (ether, $3 \times 10 \mathrm{~mL}$ ) of the aqueous layer and combining the extracts gave an organic solution which was washed with $\mathrm{H}_{2} \mathrm{O}$ and brine. The dried $\left(\mathrm{MgSO}_{4}\right)$ solution was evaporated to a colorless solid $(0.086 \mathrm{~g}, 76 \%)$ of 25: $\mathrm{mp}$ 62.5-64.5 ${ }^{\circ} \mathrm{C}$; IR (KBr) $3458(\mathrm{O}-\mathrm{H}) \mathrm{cm}^{-1}$; ${ }^{1} \mathrm{H}$ NMR $\left(\mathrm{DCCl}_{3}\right) \delta 1.31\left[\mathrm{~s}, 6 \mathrm{H},\left(\mathrm{H}_{3} \mathrm{C}\right)_{2}\right], 1.47\left[\mathrm{~s}, 6 \mathrm{H},\left(\mathrm{H}_{3} \mathrm{C}\right)_{2}\right], 1.84[\mathrm{~s}, 2$ $\left.\mathrm{H}, \mathrm{CH}_{2}\right], 2.17\left[\mathrm{~s}, 3 \mathrm{H}, \mathrm{Ar}-\mathrm{CH}_{3}\right], 2.37\left[\mathrm{~s}, 3 \mathrm{H}, \mathrm{Ar}-\mathrm{CH}_{3}\right], 4.25[\mathrm{~s}$, $1 \mathrm{H}, \mathrm{OH}], 6.50[\mathrm{~s}, 1 \mathrm{H}, \mathrm{Ar}-\mathrm{H}] ;{ }^{13} \mathrm{C} \mathrm{NMR}\left(\mathrm{DCCl}_{3}\right) \mathrm{ppm} 14.77$ $\left[\mathrm{Ar}-\mathrm{CH}_{3}\right], 15.85\left[\mathrm{Ar}-\mathrm{CH}_{3}\right], 27.84\left[\left(\mathrm{H}_{3} \mathrm{C}\right)_{2}\right], 30.88\left[\left(\mathrm{H}_{3} \mathrm{C}\right)_{2}\right], 31.98$ $\left[\mathrm{ArC}\left(\mathrm{CH}_{3}\right)_{2}\right], 53.68\left[\mathrm{CH}_{2}\right], 72.58\left[\mathrm{OC}\left(\mathrm{CH}_{3}\right)_{2}\right], 117.56-146.68$
[Ar-C]; MS (EI) calcd for $\mathrm{C}_{15} \mathrm{H}_{22} \mathrm{O}_{2}\left[\mathrm{M}^{+}\right]$234, found 234. The sample of $\mathbf{2 5}$ was used at once to prepare $\mathbf{9}$.

2-(3-Methoxyphenyl)-2-methylpropanenitrile (27). An orange mixture of $\mathrm{KOH}(20.0 \mathrm{~g} .0 .356 \mathrm{~mol})$, triethyl benzylammonium bromide (TEBA; $2.0 \mathrm{~g}, 7.46 \mathrm{mmol}$ ), and (3-methoxyphenyl)acetonitrile (26; $20.0 \mathrm{~g}, 0.135 \mathrm{~mol})$ was heated at 80 ${ }^{\circ} \mathrm{C}$ for $0.5 \mathrm{~h}$. Methyl iodide (11.50 g, $0.810 \mathrm{~mol}$ ) was added slowly over $2 \mathrm{~h}$, and the resulting yellow mixture was heated $\left(80^{\circ} \mathrm{C}\right)$ for $1 \mathrm{~h}$. Additional $\mathrm{KOH}(20.0 \mathrm{~g}, 0.356 \mathrm{~mol})$ was then added along with TEBA $(2.0 \mathrm{~g}, 7.46 \mathrm{mmol})$, and the new mixture was stirred vigorously for $0.5 \mathrm{~h}$. Methyl iodide (11.50 $\mathrm{g}, 0.081 \mathrm{~mol}$ ) was added over $1 \mathrm{~h}$, and the resulting mixture was stirred with heating $\left(80-100^{\circ} \mathrm{C}\right)$ for $5 \mathrm{~h}$. After cool ing to $\mathrm{rt}$, the reaction mixture was extracted (toluene, $5 \mathrm{~mL}$ ). The combined organic extracts were washed with water and brine and then dried $\left(\mathrm{MgSO}_{4}\right)$. Evaporation of the solvent gave an oil $(3.8 \mathrm{~g}, 84 \%)$ which was vacuum distilled $\left(100-101{ }^{\circ} \mathrm{C} / \sim 2\right.$ $\mathrm{mmHg}$ ) to a colorless oil (13.4 g, 57\%) of 27: IR (neat) 2242 $\mathrm{C} \equiv \mathrm{N} \mathrm{cm}^{-1} ;{ }^{1} \mathrm{H} \mathrm{NMR}\left(\mathrm{DCCl}_{3}\right) \delta 1.72\left[\mathrm{~s}, 6 \mathrm{H},\left(\mathrm{H}_{3} \mathrm{C}\right)_{2}\right], 3.83[\mathrm{~s}, 3$ $\left.\mathrm{H}, \mathrm{OCH}_{3}\right], 6.84[2 \mathrm{~d} 1 \mathrm{H}, \mathrm{Ar}-\mathrm{H}], 7.01[\mathrm{t}, 1 \mathrm{H}, \mathrm{Ar}-\mathrm{H}$ ], 7.05 [2d, $1 \mathrm{H}, \mathrm{Ar}-\mathrm{H}$ ], $7.31\left[\mathrm{t}, 1 \mathrm{H}, \mathrm{Ar}-\mathrm{H}\right.$ ]; ${ }^{13} \mathrm{C} \mathrm{NMR}\left(\mathrm{DCCl}_{3}\right) \mathrm{ppm} 29.08$ $\left[\left(\mathrm{H}_{3} \mathrm{C}\right)_{2}\right], 36.76\left[\mathrm{Ar}-\mathrm{C}\left(\mathrm{CH}_{3}\right)_{2}\right], 55.30\left[\mathrm{ArOCH}_{3}\right], 111.40-159.87$ $[\mathrm{Ar}-\mathrm{C}], 123.44[\mathrm{C} \equiv \mathrm{N}]$; MS (EI) calcd for $\left.\mathrm{C}_{11} \mathrm{H}_{13} \mathrm{NO}^{\mathrm{N}} \mathrm{M}^{+}\right]$175, found 175. This sample of $\mathbf{2 7}$ was used to prepare $\mathbf{2 8}$.

2-(3-Methoxyphenyl)-2-methylpropanoic Acid (28). A mixture of $27(3.8 \mathrm{~g}, 0.0217 \mathrm{~mol}), \mathrm{KOH}(5.00 \mathrm{~g}, 0.089 \mathrm{~mol})$, diethylene glycol $(30 \mathrm{~mL})$, and water $(5 \mathrm{~mL})$ were heated at $130-140{ }^{\circ} \mathrm{C}$ for 3 days and turned brown. After cooling to rt, the solution was poured into cold water. Extraction (benzene, $8 \times 40 \mathrm{~mL}$ ) of the aqueous layer followed, and then the residual aqueous layer was made acidic (concd $\mathrm{HCl}, \mathrm{pH} \sim 3$ ). The new aqueous layer was extracted (ether, $4 \times 30 \mathrm{~mL}$ ), and the combined extracts were dried $\left(\mathrm{MgSO}_{4}\right)$. Evaporation of the solvent gave a yellow solid which recrystallized (hexane) to a white solid 28 ( $3.81 \mathrm{~g}, 69 \%$ ): $\mathrm{mp} 79-80{ }^{\circ} \mathrm{C}$ (lit. $28 \mathrm{mp} 80-81.5$ $\left.{ }^{\circ} \mathrm{C}\right)$. Since spectral data were scarce on $\mathbf{2 8}$, the following data were taken: IR $(\mathrm{KBr}) 3434-2538\left(\mathrm{CO}_{2} \mathrm{H}\right), 1702(\mathrm{C}=\mathrm{O}) \mathrm{cm}^{-1}$; ${ }^{1} \mathrm{H}$ NMR $\left(\mathrm{DCCl}_{3}\right) \delta 1.58\left[\mathrm{~s}, 6 \mathrm{H},\left(\mathrm{H}_{3} \mathrm{C}\right)_{2}\right], 3.80\left[\mathrm{~s}, 3 \mathrm{H}, \mathrm{ArOCH}_{3}\right]$, 6.80 [ddd, $1 \mathrm{H}, \mathrm{Ar}-\mathrm{H}$ ], 6.95 [t, $1 \mathrm{H}, \mathrm{Ar}-\mathrm{H}$ ], 6.99 [ddd, $1 \mathrm{H}$, $\mathrm{Ar}-\mathrm{H}$ ], 7.25 [t, $1 \mathrm{H}, \mathrm{Ar}-\mathrm{H}$ ]; $\mathrm{MS}(\mathrm{EI})$ calcd for $\mathrm{C}_{11} \mathrm{H}_{14} \mathrm{O}_{3}\left[\mathrm{M}^{+}\right]$ 194, found 194. Acid 28 was converted directly to 29.

2-(3-Methoxyphenyl)-2-methyl-1-propanol (29). To a mixture of $\mathrm{LiAlH}_{4}(2.23 \mathrm{~g}, 58.9 \mathrm{mmol})$ in dry THF $(19 \mathrm{~mL})$ was added dropwise acid $\mathbf{2 8}(3.81 \mathrm{~g}, 19.6 \mathrm{mmol})$ in dry THF $(5 \mathrm{~mL})$ over $0.5 \mathrm{~h}$. After being heated at reflux $(48 \mathrm{~h})$, the resulting mixture was allowed to cool to $r t$ and was then treated cautiously with ethanol/water to destroy residual $\mathrm{LiAlH}_{4}$. A white solid formed and was filtered, and the remaining aqueous layer was extracted (ether, $5 \times 30 \mathrm{~mL}$ ). The combined extracts were washed with brine, dried $\left(\mathrm{MgSO}_{4}\right)$, and evaporated to a colorless oil 29 (2.6 g, 75\%): IR (neat) $3392(\mathrm{O}-\mathrm{H}) \mathrm{cm}^{-1}$; ${ }^{1} \mathrm{H} \mathrm{NMR}\left(\mathrm{DCCl}_{3}\right) \delta 1.32\left[\mathrm{~s}, 6 \mathrm{H},\left(\mathrm{H}_{3} \mathrm{C}\right)_{2}\right]$, $3.59\left[\mathrm{~s}, 2 \mathrm{H}, \mathrm{H}_{2} \mathrm{COH}\right.$ ], $3.81\left[\mathrm{~s}, 3 \mathrm{H}, \mathrm{ArOCH}_{3}\right], 6.75[2 \mathrm{~d}, 1 \mathrm{H}$, $\mathrm{Ar}-\mathrm{H}], 6.93[\mathrm{t}, 1 \mathrm{H}, \mathrm{Ar}-\mathrm{H}$ ] $6.97[2 \mathrm{~d}, 1 \mathrm{H}, \mathrm{Ar}-\mathrm{H}], 7.27[\mathrm{t}, 1$ $\mathrm{H}, \mathrm{Ar}-\mathrm{H}$ ]; MS (EI) calcd for $\mathrm{C}_{11} \mathrm{H}_{16} \mathrm{O}_{2}\left[\mathrm{M}^{+}\right] 180$, found 180 . The sample of $\mathbf{2 9}$ was used immediately to prepare ether $\mathbf{3 0}$.

1,1,4,4-Tetramethyl-6-methoxy-3,4-dihydro-1H-2-benzopyran (30). A solution of alcohol $29(0.989 \mathrm{~g}, 5.6 \mathrm{mmol})$, acetone $(30 \mathrm{~mL})$, and concd $\mathrm{HCl}(10 \mathrm{~mL})$ was heated and stirred at $45-50{ }^{\circ} \mathrm{C}$ for $2 \mathrm{~h}$ and at $\mathrm{rt}$ for $12 \mathrm{~h}$. The deep yellow solution was allowed to cool to rt and was then poured into ice-water. Two layers were separated, and the organic layer was extracted (ether, $5 \times 20 \mathrm{~mL}$ ). The combined extracts were washed with water $(30 \mathrm{~mL})$, saturated $\mathrm{NaHCO}_{3}(30 \mathrm{~mL})$, and brine and then was dried $\left(\mathrm{MgSO}_{4}\right)$. Evaporation of the solvent gave a colorless oil $\mathbf{3 0}(0.92 \mathrm{~g}, 75 \%)$ which was used directly to prepare 31. Spectral data for $\mathbf{3 0}$ were as follows: ${ }^{1} \mathrm{H}$ NMR $\left(\mathrm{DCCl}_{3}\right) \delta 1.26\left[\mathrm{~s}, 6 \mathrm{H},\left(\mathrm{H}_{3} \mathrm{C}\right)_{2}\right], 1.51\left[\mathrm{~s}, 6 \mathrm{H},\left(\mathrm{H}_{3} \mathrm{C}\right)_{2}\right], 3.58[\mathrm{~s}, 2$ $\mathrm{H}, \mathrm{H}_{2} \mathrm{CO}$ ], 3.80 [s, $3 \mathrm{H}, \mathrm{ArOCH}_{3}$ ], 6.73 [dd, $1 \mathrm{H}, \mathrm{Ar}-\mathrm{H}$ ], 6.82 $\left[d, 1 \mathrm{H}, \mathrm{Ar}-\mathrm{H}\right.$ ], 6.99 [d, $1 \mathrm{H}, \mathrm{Ar}-\mathrm{H}$ ]; MS (EI) calcd for $\mathrm{C}_{14} \mathrm{H}_{20} \mathrm{O}_{2}$ $\left[\mathrm{M}^{+}\right]$220, found 220 .

7-Aceto-1,1,4,4-tetramethyl-6-methoxy-3,4-dihydro-1H2-benzopyran (31). To a solution of $\mathbf{3 0}(0.989 \mathrm{~g}, 4.18 \mathrm{mmol})$, acetyl chloride $(0.74 \mathrm{~mL}, 10.0 \mathrm{mmo})$, and $\mathrm{H}_{3} \mathrm{CNO}_{2}(15 \mathrm{~mL})$ 
was added very slowly and portionwise $\mathrm{AlCl}_{3}(1.33 \mathrm{~g}, 10.0$ $\mathrm{mmol}$ ) over $1 \mathrm{~h}$. The resulting brown mixture was stirred at $\mathrm{rt}$ for $24 \mathrm{~h}$ and was then poured cautiously into ice-water (50 $\mathrm{mL}$ ). Dilute $\mathrm{HCl}(2 \mathrm{M}, \sim 5 \mathrm{~mL}$ ) was added cautiousl y to destroy residual $\mathrm{AlCl}_{3}$. The layers were separated, the aqueous layer was extracted $\left(\mathrm{H}_{2} \mathrm{CCl}_{2}, 3 \times 10 \mathrm{~mL}\right)$, and the combined organic extracts-original layer were washed with $\mathrm{H}_{2} \mathrm{O}(20 \mathrm{~mL})$, saturated aqueous $\mathrm{NaHCO}_{3}(25 \mathrm{~mL})$, and brine. Evaporation of the solvent gave a solid which was by purified by chromatography $\left(\mathrm{H}_{2} \mathrm{CCl}_{2}\right)$ and yielded a colorless solid $31(0.562 \mathrm{~g}$

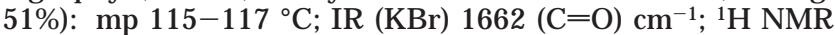
$\left(\mathrm{DCCl}_{3}\right) \delta 1.29\left[\mathrm{~s}, 6 \mathrm{H},\left(\mathrm{H}_{3} \mathrm{C}\right)_{2}\right], 1.52\left[\mathrm{~s}, 6 \mathrm{H},\left(\mathrm{H}_{3} \mathrm{C}\right)_{2}\right], 2.60[\mathrm{~s}, 3$ $\mathrm{H}, \mathrm{C}(\mathrm{O}) \mathrm{CH}_{3}$ ] $3.59\left[\mathrm{~s}, 2 \mathrm{H}, \mathrm{OCH}_{2}\right], 3.91\left[\mathrm{~s}, 3 \mathrm{H}, \mathrm{ArOCH}_{3}\right], 6.85$ $[\mathrm{s}, 1 \mathrm{H}, \mathrm{Ar}-\mathrm{H}], 7.50[\mathrm{~s}, 1 \mathrm{H}, \mathrm{Ar}-\mathrm{H}]$; MS (EI) calcd for $\mathrm{C}_{16} \mathrm{H}_{22} \mathrm{O}_{3}$ $\left[\mathrm{M}^{+}\right]$262, found 262 . Ketone 31 was used at once to prepare acid 32.

1,1,4,4-Tetramethyl-6-methoxy-3,4-di hydro-1H-2-benzopyran-7-carboxylic Acid (32). To ketone 31 (0.560 g, 0.216 $\mathrm{mmol}$ ) was added a solution of $\mathrm{LiOCl}$ (Bioguard-LiOCl $29 \%$, inert 71\%)/Clorox [5 g LiOCl (Bioguard), $20 \mathrm{~mL} \mathrm{Clorox]} \mathrm{and}$ $95 \%$ ethanol $(10 \mathrm{~mL})$ in the normal manner. ${ }^{40}$ The resulting light yellow sol ution was boiled ( $24 \mathrm{~h}$ ) and then allowed to cool to rt. The basic solution was extracted (ether, $3 \times 15 \mathrm{~mL}$ ), and the combined extracts were washed with water $(10 \mathrm{~mL})$ and brine and then were dried $\left(\mathrm{MgSO}_{4}\right)$. The original aqueous layer was acidified ( $2 \mathrm{M} \mathrm{HCl}, 10 \mathrm{~mL}, \sim \mathrm{pH} 3$ ) and then extracted (ether, $4 \times 20 \mathrm{~mL}$ ). The combined organic layers were washed with water $(20 \mathrm{~mL})$ and brine and then dried $\left(\mathrm{MgSO}_{4}\right)$. Evaporation of the solvent gave a colorless oil which crystallized (EtOAc) to give $32(0.420 \mathrm{~g}, 21 \%)$ : $\mathrm{mp} 147-149{ }^{\circ} \mathrm{C}$; IR 3443-2538 [C(O)O-H], $1691[\mathrm{C}=\mathrm{O}] \mathrm{cm}^{-1} ;{ }^{1} \mathrm{H}$ NMR $\left(\mathrm{DCCl}_{3}\right) \delta$ $1.30\left[\mathrm{~s}, 6 \mathrm{H},\left(\mathrm{H}_{3} \mathrm{C}\right)_{2}\right], 1.54\left[\mathrm{~s}, 6 \mathrm{H},\left(\mathrm{H}_{3} \mathrm{C}\right)_{2}\right], 3.61$ [s, $2 \mathrm{H}, \mathrm{H}_{2} \mathrm{CO}$ ], $4.07\left[\mathrm{~s}, 3 \mathrm{H}, \mathrm{ArOCH}_{3}\right], 6.93[\mathrm{~s}, 1 \mathrm{H}, \mathrm{Ar}-\mathrm{H}], 7.89[\mathrm{~s}, 1 \mathrm{H}, \mathrm{Ar}-$ $\mathrm{H}$ ]; MS (EI) calcd for $\mathrm{C}_{15} \mathrm{H}_{20} \mathrm{O}_{4}\left[\mathrm{M}^{+}\right] 264$, found 264 . The acid 32 was used directly to obtain the target compound $\mathbf{1 0}$.

1-(3-Hydroxy-5,6,7,8-tetrahydro-5,5,8,8-tetramethylnaphthalen-2-yl)ethanone (34). To a solution of ether $33^{32}$ $(0.050 \mathrm{~g}, 0.23 \mathrm{mmol})$, acetyl chloride $(0.049 \mathrm{~g}, 0.69 \mathrm{mmol})$, and $\mathrm{H}_{3} \mathrm{CNO}_{2}(5 \mathrm{~mL})$ was added slowly and portionwise $\mathrm{AlCl}_{3}(0.092$ $\mathrm{g}, 28.9 \mathrm{mmol}$ ) over $1 \mathrm{~h}$. After stirring at rt (4 h), the brown solution was poured into ice-water $(10 \mathrm{~mL})$. Two layers were separated, and the aqueous layer was extracted (ether, $2 \times$ $10 \mathrm{~mL}$ ). The combined organic layers were washed with $\mathrm{H}_{2} \mathrm{O}$ $(20 \mathrm{~mL})$, saturated aqueous $\mathrm{NaHCO}_{3}(15 \mathrm{~mL})$, and brine. After drying $\left(\mathrm{MgSO}_{4}\right)$ and evaporation of the solvent from the solution, ketone $34(0.045 \mathrm{~g}, 75 \%)$ was obtained as a light yellow solid: $\mathrm{mp} \mathrm{96-98}{ }^{\circ} \mathrm{C}$; IR $(\mathrm{KBr}) 1664 \mathrm{~cm}^{-1}$; ${ }^{1} \mathrm{H} N M R$ $\left(\mathrm{DCCl}_{3}\right) \delta 1.27\left[\mathrm{~s}, 6 \mathrm{H},\left(\mathrm{H}_{3} \mathrm{C}\right)_{2}\right], 1.30\left[\mathrm{~s}, 6 \mathrm{H},\left(\mathrm{H}_{3} \mathrm{C}\right)_{2}\right], 1.68[2 \mathrm{t}$, $\left.4 \mathrm{H}, \mathrm{J}=6.0 \mathrm{~Hz},\left(\mathrm{H}_{2} \mathrm{C}\right)_{2}\right], 2.59\left[\mathrm{~s}, 3 \mathrm{H}, \mathrm{CH}_{3}\right], 3.89\left[\mathrm{~s}, 3 \mathrm{H}, \mathrm{OCH}_{3}\right]$, $6.85[\mathrm{~s}, 1 \mathrm{H}, \mathrm{Ar}-\mathrm{H}], 7.73[\mathrm{~s}, 1 \mathrm{H}, \mathrm{Ar}-\mathrm{H}], 11.87[\mathrm{~s}, 1 \mathrm{H}, \mathrm{OH}]$ MS (EI) calcd for $\mathrm{C}_{17} \mathrm{H}_{24} \mathrm{O}_{2}\left[\mathrm{M}^{+}\right] 260$, found 260. Ketone 34 was converted to acid 35.

3-Methoxy-5,6,7,8-tetrahydro-5,5,8,8-tetramethylnaphthalene-2-carboxylic Acid (35). A mixture of ketone 34 $(0.900 \mathrm{~g}, 3.46 \mathrm{mmol})$, a solution of $\mathrm{LiOCl}$ and Clorox [40 g $\mathrm{LiOCl}$ (Bioguard), $80 \mathrm{~mL}$ Clorox], and 95\% ethanol $(45 \mathrm{~mL}$ ) was boiled for $24 \mathrm{~h}$ and then allowed to cool to rt. An aqueous solution of $\mathrm{Na}_{2} \mathrm{~S}_{2} \mathrm{O}_{5}(25 \%, 35 \mathrm{~mL})$ was slowly added to the reaction mixture which was then acidified with $6 \mathrm{M} \mathrm{HCl}(10$ $\mathrm{mL}, \mathrm{pH} \sim 3$ ). Extraction (ether, $4 \times 20 \mathrm{~mL}$ ) of this mixture and then washing of the combined extracts with $\mathrm{H}_{2} \mathrm{O}(20 \mathrm{~mL})$ and brine gave a new solution which was dried $\left(\mathrm{MgSO}_{4}\right)$. Evaporation of the solvent gave a very light yellow solid 35 (0.420 g, 44\%): $\mathrm{mp} 136.5-138{ }^{\circ} \mathrm{C}$; IR (K Br) 3269 (broad) $[\mathrm{C}(\mathrm{O}) \mathrm{O}-\mathrm{H}], 1731[\mathrm{C}=\mathrm{O}] \mathrm{cm}^{-1} ;{ }^{1} \mathrm{H} N M R\left(\mathrm{DCCl}_{3}\right) \delta 1.28[\mathrm{~s}, 6$ $\left.\mathrm{H},\left(\mathrm{H}_{3} \mathrm{C}\right)_{2}\right], 1.31\left[\mathrm{~s}, 6 \mathrm{H},\left(\mathrm{H}_{3} \mathrm{C}\right)_{2}\right], 1.69\left[\mathrm{t}, 4 \mathrm{H}, \mathrm{J}=5 \mathrm{~Hz}, \mathrm{CH}_{2}\right]$, $4.06\left[\mathrm{~s}, 3 \mathrm{H}, \mathrm{OCH}_{3}\right], 6.93[\mathrm{~s}, 1 \mathrm{H}, \mathrm{Ar}-\mathrm{H}], 8.12[\mathrm{~s}, 1 \mathrm{H}, \mathrm{Ar}-\mathrm{H}]$; ${ }^{13} \mathrm{C} \mathrm{NMR}\left(\mathrm{DCCl}_{3}\right) \mathrm{ppm} 31.58\left[\left(\mathrm{H}_{3} \mathrm{C}\right)_{2}\right], 31.67\left[\left(\mathrm{H}_{3} \mathrm{C}\right)_{2}\right], 33.83$ $\left[\mathrm{CH}_{2}\right], 34.60\left[\mathrm{CH}_{2}\right], 34.65\left[\mathrm{ArC}\left(\mathrm{CH}_{3}\right)_{2}\right], 35.09\left[\mathrm{ArC}\left(\mathrm{CH}_{3}\right)_{2}\right], 56.47$ $\left[\mathrm{OCH}_{3}\right], 109.15-155.53[\mathrm{Ar}-\mathrm{C}], 165.60[\mathrm{C}=\mathrm{O}]$; MS (EI) calcd for $\mathrm{C}_{16} \mathrm{H}_{22} \mathrm{O}_{3}\left[\mathrm{M}^{+}\right]$262, found 262. Acid 35 was used directly to prepare ester $\mathbf{1 1 .}$

2-(2,3-Dihydro-1,4-benzodioxan-6-yl)-3-buten-2-ol (37). To a solution of commercial ketone 36 (4.0 g., $22.45 \mathrm{mmol})$ in
THF (25 mL) was added dropwise vinylmagnesium bromide [prepared from $\mathrm{Mg}(1.52 \mathrm{~g}, 62.53 \mathrm{mmol})$ and vinyl bromide $(10 \mathrm{~g}, 93.45 \mathrm{mmol})$ in THF $(10 \mathrm{~mL})$ ] over $0.25 \mathrm{~h}$. After stirring at rt for $10 \mathrm{~h}$, the mixture was cooled in a water bath, and a saturated aqueous solution $(20 \mathrm{~mL})$ of $\mathrm{H}_{4} \mathrm{NCl}$ was added dropwise to effect decomposition. Separation and extraction (ether, $4 \times 50 \mathrm{~mL}$ ) of the aqueous layer gave a solution of combined extracts which was washed with saturated, aqueous $\mathrm{NaCl}$. Drying of the organic solution and evaporation of the solvent gave slightly crude $37(4.78 \mathrm{~g}, 103 \%)$ as a yellow oil: IR (neat) 3700-3100 (O-H) cm ${ }^{-1}$; ${ }^{1} \mathrm{H}$ NMR $\left(\mathrm{DCCl}_{3}\right) \delta 1.60[\mathrm{~s}$, $3 \mathrm{H}, \mathrm{H}(10)], 4.23$ [s, $4 \mathrm{H}, \mathrm{H}(2,3)], 5.11[\mathrm{dd}, \mathrm{J}$ cis $=10.6 \mathrm{~Hz}$, J gem $=1.08 \mathrm{~Hz}, 1 \mathrm{H}, \mathrm{H}(12)], 5.27[\mathrm{dd}, \mathrm{J}$ trans $=17.2 \mathrm{~Hz}$, J gem $=1.08$ $\mathrm{Hz}$, J gem $=1.08 \mathrm{~Hz}, 1 \mathrm{H}, \mathrm{H}(12)], 6.12[\mathrm{dd}, \mathrm{J}$ trans $=17.3 \mathrm{~Hz}$, J cis $=10.6 \mathrm{~Hz}, \mathrm{H}(11)] 6.8-6.99[\mathrm{~m}, \mathrm{Ar}-\mathrm{H}, 3 \mathrm{H}, \mathrm{H}(5,7,8)]$; HRMS calcd for $\mathrm{C}_{12} \mathrm{H}_{14} \mathrm{O}_{3}\left[\mathrm{M}^{+}\right]$206.0942, found 206.0938. This sample of $\mathbf{3 7}$ was used without further purification to prepare salt $\mathbf{3 8}$.

[3-(2,3-Dihydro-1,4-benzdioxan-6-yl)-2-buten-1-yl]triphenylphosphonium Bromide (38). To a stirred suspension of $\mathrm{Ph}_{3} \mathrm{P} \cdot \mathrm{HBr}(2.61 \mathrm{~g}, 4.92 \mathrm{mmol})$ in dry methanol $(20 \mathrm{~mL})$ was added dropwise al cohol $\mathbf{3 7}(1.01 \mathrm{~g}, 4.92 \mathrm{mmol})$ in dry methanol (30 mL) over $10 \mathrm{~min}$ at rt under $\mathrm{N}_{2}$. After stirring at rt for 10 $\mathrm{h}$, the suspension was concentrated to about $5 \mathrm{~mL}$ and was then transferred to a large beaker. Dry ether was added slowly with stirring to complete the precipitation. Filtration gave a solid which was washed (dry ether) and then was dissolved in dry methanol $(\sim 15 \mathrm{~mL})$. Ether was added to cloudiness, and the resulting mixture was chilled in the freezer. Filtration and drying the solid gave fine, white crystals of 38 (2.22 g,

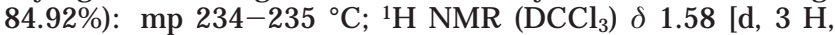
$\mathrm{H}(01)], 4.22[\mathrm{~s}, 4 \mathrm{H}, \mathrm{H}(2,3)], 4.84[\mathrm{dd}, \mathrm{J} \mathrm{HP}=15.1 \mathrm{~Hz}, \mathrm{~J} \mathrm{HH}=$ $8.1 \mathrm{~Hz}, \mathrm{H}(12)], 5.57$ [m, $1 \mathrm{H}, \mathrm{H}(11)], 6.88$ [m, $3 \mathrm{H}, \mathrm{H}(5,7,8)]$, $7.65-7.93\left[\mathrm{~m}, 14 \mathrm{H}, \mathrm{Ar}-\mathrm{H}, \mathrm{P}\left(\mathrm{C}_{6} \mathrm{H}_{5}\right)_{3}\right]$. In view of the rarity of such salts, an elemental analysis was obtained and resulted in the identification of a monohydrate. Anal. $\left(\mathrm{C}_{30} \mathrm{H}_{28} \mathrm{O}_{2} \mathrm{PBr}\right.$. $\left.\mathrm{H}_{2} \mathrm{O}\right) \mathrm{C}, \mathrm{H}$. Salt 38 was used directly to obtain 13.

2,2,4,4-Tetramethyl-6-nitrothiochroman (40). To a solution of thioether $39^{5}(5.13 \mathrm{~g}, 24.8 \mathrm{mmol})$ in freshly distilled $\mathrm{Ac}_{2} \mathrm{O}(5 \mathrm{~mL})$ at $0{ }^{\circ} \mathrm{C}$ was added slowly a mixture of cold, concd $\mathrm{HNO}_{3}(3.54 \mathrm{~mL})$ and $\mathrm{Ac}_{2} \mathrm{O}(9 \mathrm{~mL})$ over $10 \mathrm{~min}$. After being stirred for $2 \mathrm{~h}$, the reaction mixture was poured into a sol ution of saturated, aqueous $\mathrm{NaHCO}_{3}$. Extraction $\left(\mathrm{H}_{2} \mathrm{CCl}_{2}, 3 \times 40\right.$ $\mathrm{mL}$ ) of the water layer and combining the extracts and organic layer gave a solution which was washed with water and brine and then was dried $\left(\mathrm{Na}_{2} \mathrm{SO}_{4}\right)$. Evaporation of the solvent gave a solid which was recrystallized (hexane) to yield $\mathbf{4 0}$ (1.6 g, 27\%): $\mathrm{mp} 103-107^{\circ} \mathrm{C}$; ${ }^{1} \mathrm{H} N M R\left(\mathrm{DCCl}_{3}\right) \delta 1.10\left[\mathrm{~s}, 3 \mathrm{H},\left(\mathrm{H}_{3} \mathrm{C}\right)_{2}\right]$, $1.37\left[\mathrm{~s}, 3 \mathrm{H},\left(\mathrm{H}_{3} \mathrm{C}\right)_{2}\right], \mathrm{I} .52\left[\mathrm{~s}, \mathrm{SC}\left(\mathrm{CH}_{3}\right)_{2}\right], 1.56\left[\mathrm{~s}, 3 \mathrm{H}, \mathrm{SC}\left(\mathrm{CH}_{3}\right)_{2}\right]$, $2.03\left[\mathrm{~m}, 3 \mathrm{H}, \mathrm{CH}_{2}\right], 8.01[\mathrm{~d}, 1 \mathrm{H}, \mathrm{Ar}-\mathrm{H}], 8.24$ [d, $\left.2 \mathrm{H}, \mathrm{Ar}-\mathrm{H}\right]$. The sample of $\mathbf{4 0}$ was used directly to prepare amine $\mathbf{4 1}$.

2,2,4,4-Tetramethyl-6-aminothiochroman (41). To chroman $40(0.800 \mathrm{~g}, 3.18 \mathrm{mmol})$ in acetic acid $(29 \mathrm{~mL})$ and water $(6 \mathrm{~mL})$ was added dropwise with stirring $\mathrm{TiCl}_{3} / \mathrm{HCl}(33.00 \mathrm{~g}$, $21.39 \mathrm{mmol}$ ). After stirring for $2 \mathrm{~h}(\mathrm{rt})$, the reaction mixtrure was cooled $\left(0^{\circ} \mathrm{C}\right)$, and $\mathrm{NaOH}(30 \%, 130 \mathrm{~mL})$ was added slowly. Extractions (EtOAc, $4 \times 35 \mathrm{~mL}$, and $\mathrm{H}_{2} \mathrm{CCl}_{2}, 2 \times 40 \mathrm{~mL}$ ) of the mixture followed, and combining the extracts and organic layer gave a solution which was washed with $\mathrm{H}_{2} \mathrm{O}$ and saturated $\mathrm{NaHCO}_{3}(2 \times 50 \mathrm{~mL})$. The dried $\left(\mathrm{Na}_{2} \mathrm{SO}_{4}\right)$ solution was evaporated to an oil which was separated via chromatography over silica gel (hexane: $\mathrm{H}_{2} \mathrm{CCl}_{2}, 1: 1$ ) and led to $\mathbf{4 1}$ as a

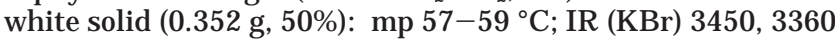
$(\mathrm{N}-\mathrm{H}) \mathrm{cm}^{-1} ;{ }^{1} \mathrm{H} \mathrm{NMR}\left(\mathrm{DCCl}_{3}\right) \delta 1.36\left[\mathrm{~s}, 6 \mathrm{H},\left(\mathrm{H}_{3} \mathrm{C}\right)_{2}\right], 1.39[\mathrm{~s}$, $\left.6 \mathrm{H}, \mathrm{SC}\left(\mathrm{CH}_{3}\right)_{2}\right], 1.90\left[\mathrm{~s}, 2 \mathrm{H}, \mathrm{CH}_{2}\right.$ ] 3.50 [bs, $2 \mathrm{H}, \mathrm{NH}_{2}$ ], 6.44 $[\mathrm{d}, 1 \mathrm{H}, \mathrm{Ar}-\mathrm{H}], 6.75[\mathrm{~s}, 1 \mathrm{H}, \mathrm{Ar}-\mathrm{H}], 9.92[\mathrm{~d}, 1 \mathrm{H}, \mathrm{Ar}-\mathrm{H}]$. The sample of $\mathbf{4 1}$ was used directly to prepare $\mathbf{1 6}$.

In Vitro Growth Inhibition. Cultures were plated with 96-well microtiter plates in volumes of $150 \mu \mathrm{L}$ at a concentration of 2500 cells/well. The next day, retinoids were added at $4 \mathrm{X}$ concentrations in $50 \mathrm{uL}$ of media resulting in $10^{-9}, 10^{-8}$, $10^{-7}, 10^{-6}$, and $10^{-5} \mathrm{M}$ final concentrations of each retinoid. Control cultures were treated with the same volume of DMSO. After 3 days of treatment, the cell density in each well was determined by fixing the cells in trichloroacetic acid and 
staining the cytoplastic proteins with sulforhodamine B (SRB). After rinsing, the SRB was solubilized in Tris $\mathrm{HCl}$, and the optical density of each culture was determined with a MR600 microtiterplate reader. Each experiment was performed in triplicate, and the three values for each treatment were averaged. The average OD of the treated cultures was divided by that of the control cultures treated with solvent alone. To determine the percent growth inhibition, this ratio was subtracted from 1 and multiplied by 100 .

In Vivo Tumor Xenographs. Cells in log phase growth were harvested by trypsinization, resuspended in MEM culture medium, and centrifuged at $3000 \mathrm{rpm}$ for $10 \mathrm{~min}$. The pellets were resuspended in MEM culture medium at a concentration of $1 \times 10^{7} \mathrm{cell} \mathrm{s} / \mathrm{mL}$ before implantation into mice. Five-week old female athymic nu/nu mice (Harlan Sprague-Dawley, Indianapolis, IN) were housed in a laminar flow room under sterile conditions at $83-85^{\circ} \mathrm{F}$. The mi ce were quarantined for 1 week prior to the beginning of the study and were allowed access to autoclaved food (Purina 5001 mouse/rat sterilizable diet, St. Louis, MO) and water ad libitum. Animals were injected with $1 \times 10^{7}$ cells into the right scapular region with a 24-gauge needle $/ 1 \mathrm{~cm}^{3}$ tuberculin syringe (Becton Dickinson, Rutherford, NJ ). Twenty-four hours after tumor implantation, animals were randomized into 4 treatment groups of 5 animals each. Retinoids were administered daily po beginning 5 days after tumor implantation with a 20-gauge intragastric feeding tube (Popper \& Sons, New Hyde Park, NY), 5 days/week, at doses of 10 or $20 \mathrm{mg} / \mathrm{kg} /$ day in $0.1 \mathrm{~mL}$ of super-refined sesame oil (Corda, Inc., Parisppany, NJ ). Tumors were measured with calipers thrice weekly, and tumor volumes were calculated using the formula: volume $=$ length $\times$ width $\times$ heigth. Animal weights were recorded thrice weekly, and clinical signs of overall health status and cutaneous toxicities were recorded weekly.

Receptor Expression. RNA was isolated using the QuickPrep Kit (Amershsam Pharmacia Biotech, Piscataway, NJ ), and CDNA was synthesized with Superscript reverse transcriptase (GibcoBRL, Gaithersburg, MD) according to the manufacturer's instructions. The specific primers and annealing conditions used for the PCR reactions were previously described and demonstrated to be specific for the individual receptor subtypes. ${ }^{41}$ The RXR expression was not evaluated because a human $R X R \gamma$ gene has not been cloned. All PCR reactions were performed under the same conditions in a 50$\mu \mathrm{L}$ reaction volume containing $5 \mu \mathrm{L}$ of $\mathrm{CDNA}$ from reverse transcription, $1.25 \mathrm{U}$ of Taq DNA polymerase, and the buffer provided. Initial denaturation was performed at $94{ }^{\circ} \mathrm{C}$ for 5 min, followed by 35 cydes of $45 \mathrm{~s}$ at $94^{\circ} \mathrm{C}, 45 \mathrm{~s}$ at the indicated annealing temperature, and $1 \mathrm{~min}$ at $72^{\circ} \mathrm{C}$ with an ending of 15 -min cycle at $72{ }^{\circ} \mathrm{C}$. Negative control reactions consisted of rt-PCR reactions without added RNA.

Receptor Activation. The CV-1 cells were plated in 6-well culture plates at a density of $7.5 \times 10^{4}$ cells/well and, after 24 $\mathrm{h}$, were cotransfected with a retinoic acid receptor expression vector (pECE-hRAR $\alpha, p E C E-h R A R ~ \beta, p E C E-h R A R ~ \gamma, p S G 5-$ $\mathrm{mRXR} \alpha$, pSG5-mRXR $\beta$, or $\mathrm{pSG} 5-\mathrm{mRXR} \gamma)$, a retinoic acid responsive reporter plasmid ( $\beta$ RARE-tk-CAT), and a transfection control plasmid (p) ATLac) using FuGE NE 6 transfection reagent (Boehringer Mannheim Corp., Indianapol is, IN). The $\beta$ RARE-tkCAT plasmid contained the chloramphenicol acetyltransferase gene (CAT) driven by the thymidine kinase (tk) promoter and the $\mathrm{RAR} \beta$ retinoic acid response element (RARE). The pJ ATLac plasmid contained the $\beta$-galactosidase ( $\beta \mathrm{Gal}$ ) gene driven by the $\beta$ actin promoter. About $16-18 \mathrm{~h}$ after transfection, retinoids or DMSO (solvent) was added to the cells. The retinoids were administered at 10 -fold dilutions of concentrations ranging from $10^{-5}$ to $10^{-10} \mathrm{M}$. The concentration of DMSO in all treated and control cultures was $0.01 \%$ which was not cytotoxic to the cells. After incubation for $24 \mathrm{~h}$, cell lysates were prepared and assayed for reporter expression using CAT and $\beta$ Gal ELISA kits (Boehringer Mannheim Corp., Indianapolis, IN) according to the manufacturer's instructions. The CAT expression levels were corrected for transfection efficiency by dividing by the $\beta$ Gal expression levels. Each experiment was performed in triplicate and repeated at least twice.

Anti-AP-1 Activity. The SCC-2 cells were plated at $3 \times$ $10^{5}$ cells/well in 6 -well plates $24 \mathrm{~h}$ before transfection. The cultures were cotransfected with a CAT reporter plasmid driven by the collagenase promoter (Col-CAT) and the pJ ATLac plasmid DNA using FuGE NE 6 transfection reagent (Boehringer Mannheim Corp., Indianapolis, IN) according to the manufacturer's instructions. After incubation for $24 \mathrm{~h}$, the media was replenished, and retinoids were added at a concentration of $10^{-5} \mathrm{M}$. After another $48 \mathrm{~h}$, CAT and $\beta \mathrm{Gal}$ expressions were quantitated as described above. All values were divided by the value of control cultures treated with DMSO to determine the percent activities. Each experiment was performed in duplicate and repeated twice.

Acknowledgment. We gratefully acknowledge partial support of this work by the National Institutes of Health through grants from the National Cancer Institute (CA-73639 and F 3CA83168). We are also pleased to acknowledge funding for the Varian I nova $400 \mathrm{MHz}$ NMR spectrometer in the Oklahoma Statewide Shared NMR F acility by the National Science F oundation (BI R9512269), the Oklahoma State Regents for Higher Education, the W. M. Keck F oundation, and Conoco, Inc. The HNSCC cell lines were kindly supplied by Thomas Carey from the University of Michigan. The RAR expression vectors and reporter plasmids were gifts of Magnus Pfahl, and the RXR expression vectors were gifts of Pierre Chambon.

\section{References}

(1) (a) Moon, R. C.; Mehta, R. G.; Rao, K. V. N. Retinoids and Cancer In Experimental Animals. In The Retinoids-Biology, Chemistry and Medicine; Sporn, M. B., Roberts, A. B., Goodman, D. S., Eds.; Raven Press: New York, 1994. (b) Hong, W. K.; Iti, L. M. Retinoids in Human Cancer. In The Retinoids-Biology, Chemistry, and Medicine; Sporn, M. B., Roberts, A. B., Goodman, D. S., Eds.; Raven Press: New York, 1994.

(2) (a) Armstrong, R. B.; Ashenfelter, K. O.; Eckhoff, C.; Levin, A. A.; Shapiro, S. S. General and Reproductive Toxicology of Retinoids. In The Retinoids-Biology, Chemistry, and Medicine Sporn, M. B., Roberts, A. B., Goodman, D. S., Eds.; Raven Press: New York, 1994. (b) Kamm, J. J .; Ashenfleter, K. O.; Ehmann, C. W. Preclinical and Clinical Toxicology of Selected Retinoids. In The Retinoids; Sporn, M. B., Roberts, A. B. Goodman, D. S., Eds.; Academic Press: Orlando, 1984.

(3) Gross, E. G.; Helfgott, M. A. Retinoids and the Eye. Dermatol Clin. 1992, 10, 521-531.

(4) Waugh, K. M.; Berlin, K. D.; Ford, W. T.; Holt, E. M.; Carroll, J . P.; Schomber, P. R.; Schiff, L.J . Synthesis and Characterization of Selected Heteroarotinoids. Pharmacological Activity as Assessed in Vitamin A Deficient Hamster Tracheal Organ Cultures. Single-Crystal X-ray Diffraction Analysis of 4,4 Dimethylthiochroman-6-yl Methyl Ketone 1,1-Dioxide and Ethyl (E)-4-[2-(4,4-Dimethylthiochroman-6-yl)-1-propenyl ]benzoate. ] Med. Chem. 1985, 27, 116-124.

(5) Spruce, L. W.; Gale, J . B.; Berlin, K. D.; Verma, A. K.; Breitman, T. R.; J i, X.; van der Helm, D. Novel Heteroarotinoids: Synthesis and Biological Activity. J. Med. Chem. 1991, 34, 430-439.

(6) Spruce, L. W.; Rajadhyaksha, S. N.; Berlin, K. D.; Gale, J . B Miranda, E. T.; Ford, W. T.; Blossey, E. C.; Verma, A. K.; Hossain, M. B; van der Helm, D.; Breitman, T. R. Heteroarotinoids. Synthesis, Characterization, and Biological Activity in Terms of an Assessment of These Systems to I nhibit Induction of Ornithine Decarboxylase Activity and to Induce Terminal Differentiation of HL- 60 Cells. J . Med. Chem. 1987, 30, 14741482.

(7) Benbrook, D. M.; Madler, M. M.; Spruce, L. W.; Birckbichler, P. J .; Nelson, E. C.; Subramanian, S.; Weerasekare, G. M.; Gale J. B.; Patterson, J r., M. K.; Wang, B.; Wang, W.; Lu, S.; Rowland, T. C.; DiSivestro, P.; Lindamood, C.; Hill, D. L.; Berlin, K. D. Biologically Active Heteroarotinoids Exhibit Anticancer Activity and Decreased Toxicity. J. Med. Chem. 1997, 40, 3567-3583.

(8) Benbrook, D. M.; Subramanian, S.; Gale, J. B.; Liu, S.; Brown C. W.; Boehm, M. F.; Berlin, K. D. Synthesis and Characterization of Heteroarotinoids Demonstrates Structure-Activity Re lationships. J . Med. Chem. 1998, 41, 3753-3757. 
(9) (a) Mangelsdorf, D. J .; Umesono, K.; Evans, R. M. The Retinoid Receptors. In The Retinoids-Biology, Chemistry, and Medicine; Sporn, M. B., Roberts, A. B., Goodman, D. S., Eds.; Raven Press: New York, 1994. (b) Dawson, M. I. Retinoids. In Burger's Medicinal Chemistry and Drug Discovery, 5th ed.; Wolff, M. E., Ed.; Wiley: New York, 1996.

(10) Cooper, J. S.; Pajak, T. F.; Rubin, P.; Tupchong, L.; Brady, L. W.; Leibel, S. A.; Laramore, G. E.; Marcial, V. A.; Davis, L. W.; Cox, J . D. Second Malignancies in Patients Who Have Head and Neck Cancers: Incidence, Effect on Survival and Implications for Chemoprevention Based on the RTOG Experience. Int. J . Radiat. Oncol. Biol. Phys. 1989, 19, 449-456.

(11) Slaughter, D. P.; Southwick, H. W.; Smejkal, W. Field Cancerization in Oral Stratified Squamous Epithelium: Clinical Implications of Multicentric Origin. Cancer 1953, 6, 963-968.

(12) Lotan, R. Squamous Cell Differentiation Markers in Normal Premalignant, and Malignant E pithelium: Effects of Retinoids. J. Cell. Biochem. 1993, 17, 167-174.

(13) Wolbach, S. B.; Howe, P. R. Tissue Changes F ollowing Deprivation of F at Soluble A Vitamin. J . Exp. Med. 1925, 42, 753-777.

(14) Lippman, S. M.; Batsakis, J . G.; Toth, B. B.; Weber, R. S.; Lee J. J .; Martin, J. W.; Hays, G. L.; Goepfert, H.; Hong, W. K. Comparison of Low-Dose I sotretinoin Therapy with $\beta$-Carotene for Prevention of Oral Carcinogenesis. N. Engl. J . Med. 1993, $328,15-20$

(15) Chiesa, F.; Tradati, N.; Marazzara, M.; Rossi, N.; Boraccchi, p.; Mariani, L.; Formelli, F.; Giardini, R.; Costa, A.; DePalo, G. Veronesi, U. Fenretinide (4HPR) in Chemoprevention of Oral Leukoplakia. J. Cell. Biochem. 1993, 17 (Suppl), 255-261.

(16) Kurie, J . M.; Lippman, S. M.; Hong, W. K. Potential of Retinoids in Cancer Prevention. Cancer Treat. Rev, 1994, 20, 1-10.

(17) Benner, S. E.; Pajak, T. F.; Lippman, S. M.; Early, C.; Hong, W. $K$. Prevention of Second Primary Tumors with Isotretinoin in Patients with Squamous Cell Carcinoma of the Head and Neck: Long Term Followup. J . Natl. Cancer Inst. 1994, 86, 140-141.

(18) Dimery, I. W.; Hong, W. K.; Lee, J .J .; Guillory-Perez, C.; Pham. F.; Fritsche, J r., H. A.; Lippman, S. M. Phase I Trial of AlphaTocopherol Effects on 13-cis-Retinoic Acid Toxicity. Ann. Oncol . 1997, 8, 85-89.

(19) Shalinsky, D. R.; Bischoff, E. D.; Gregory, M. L.; Gottaris, M. M.; Hayes, J. S.; Lamph, W. W.; Heyman, R. A.; Shirley, M. A. Cooke, T. A.; Davies, P. J.; Thomazy, V. Retinoid-Induced Suppression of Squamous Cell Differentiation in Human Oral Squamous Cell Carcinoma Xenographs (line 1483) in Athymic Nude Mice. Cancer Res. 1995, 55, 3183-3191.

(20) Scher, R. L.; Saito, W.; Dodge, R. K.; Richtsmeier, W. J .; Fine R. L. Fenretinide-Induced Apoptosis of Human Head and Neck Squamous Carcinoma Cell Lines. Otol. Head Neck Surg. 1998, $118,464-471$.

(21) Cooper, M. P.; Klassen, I.; Brakenhoff, R. H.; Cloos, J .; Snow, G. B.; Braakhuis, B. J. All-trans-Retinoic Acid Induced Gene Expression and Growth I nhibition in Head and Neck Cancer Cell Lines. Oral Oncol. 1997, 33, 270-274.

(22) Eicher, S. A.; Lotan, R. Differential Effects of Retinoic Acid and $\mathrm{N}$-(4-Hydroxyphenyl)retinamide on Head and Neck Squamous Cell Carcinoma Cells. Laryngoscope 1996, 106, 1471-1475.

(23) Lotan, R. Retinoids and Their Receptors in Modulation of Differentiation, Development, and Prevention of Head and Neck Cancers. Anticancer Res. 1996, 16, 2415-2419.

(24) Mourad, W. A. Bruner, J. M. Vallieres, E: McName, C. Alabdulwahed, S.; Scott, K.; Oldring, D. J . The Effect of High Dose Vitamin A on the Morphology and Proliferative Ability of Xenograph Lung and Neck Cancer. In Vivo 1996, 10, 329-33.

(25) Kagechika, H.; Kawachi, E.; Hashimoto, I.; Himi, T.; Shudo, K. Retinobenzoic Acids. 1. Structure-Activity Relationships of Aromatic Acids With Retinoidal Activity. J . Med. Chem. 1988, 31, 2182-2192.

(26) Apfel, C.; Bauer, F.; Crettaz, M.; Forni, L.; Kamber, M.; Kaufmann, F.; LeMotte, P.; Pirson, W.; Klaus, M. A Retinoic Acid Receptor $\alpha$ Antagonist Selectivity Counteracts Retinoic Acid Effects. Proc. Natl. Acad. Sci. U.S.A. 1992, 89, 7129-7133.
(27) Wang, B.; Liu, S.; Borchardt, R. T. Development of a Novel Redox-Sensitive Protecting Group for Amines Which Utilize a Facilitated Lactonization Reaction. J . Org. Chem. 1995, 60, 539543.

(28) Nakatani, K.; Numata, S.; Inoue, T.; Fujisawa, K. K.; Kawasaki T. I.; Toyama, T.; Tachibana, H.; Udagave, T.; Gohbara, M. UP 254135, U.S. Patent 4397864; Chem. Abstr. 1982, 97, 5964e.

(29) Boehm, M. F.; Zhang, L.; Zhi, L.; Badea, B. A.; White, S. K. Mais, D. E.; Berger, E.; Suto, M. C.; Goldman, M. E.; Heyman, R. A. Synthesis and Structure-Activity Relationships of Novel Retinoid X Receptor-Selective Retinoids. J . Med. Chem. 1994, 37, 2930-2941.

(30) Mangelsdorf, D. J .; Umesono, K.; Evans, R. M. In TheRetinoidsBiology, Chemistry, and Medicine; Sporn, M. B., Roberts, A. B. Goodman, D. S., Eds.; Raven Press: New York, 1994; pp 319349.

(31) Pfahl, M. Nuclear Receptor/AP-1 Interaction. Endocrinol. Rev. 1993, 14, 651-658.

(32) Chen, J. Y.; Penco, S.; Ostrowski, J .; Balaguer, P.; Pons, M.; Starrett, J . E.; Preczek, P.; Chambon, P.; Gronemeyer, H. RARSpecific Agonist/Antagonists Which Dissociate Transactivation and AP1 Tranrepression Inhibit Anchorage-Dependent Cell proliferation. EMBO 」. 1995, 14, 1187-1197.

(33) Fanjul, A.; Dawson, M. I.; Hobbs, P. D.; J ong, L.; Cameron, J . F.; Harlev, E.; Graupner, G.; Lu, C.-P.; Pfahl, M. A Novel Class of Retinoids with Selective Inhibition of AP-1 Exhibit AntiProliferative Activity. Nature 1994, 372, 107-111.

(34) Grandis, J. R.; Zeng, Q.; Tweardy, D. J . Retinoic Acid Normalizes the Increased Gene Transcription Rate of TGF-AIpha and EGFR in Head and Neck Cancer Cell Lines. Nature Med. 1996, 2, 237240.

(35) Issing, W. J .; Wustrow, T. P. Expression of Retinoic Acid Receptors in Squamous Cell Carcinomas and Their Possible Implication in Chemoprevention. Anticancer Res. 1996, 16, 2373-2377.

(36) Oridate, N.; Esumi, N.; Lotan, D.; Hing, W. K.; Rochette-E gly, C.; Chambon, P.; Lotan, R. I mplication of Retinoic Acid Receptor Gamma in Squamous Differentiation and Response to Retinoic Acid in Head and Neck SqSCC/Y 1 Squamous Carcinoma Cells. Oncogene 1996, 12, 2019-2028.

(37) Lotan, R.; Dawson, M. I.; Zou, C.-C.; J ong, L.; Lotan, D.; Zou, C.-P. Enhanced Efficacy of Combinations of Retinoic Acid- and Retinoid X Receptor-Selective Retinoids and $\alpha$-Interferon in Inhibition of Cervical Carcinoma Cell proliferation. Cancer Res. 1995, 55, 232-236

(38) Shalinsky, D. R.; Bischoff, E. D.; Lamph, W. W.; Zhang, L.; Boehm, M. F.; Davies, P. J . A.; Nadzan, A. M.; Heyman, R. A. A Novel Retinoic Acid Receptor-Selective Retinoid, ALRT1550, Has Potent Antitumor Activity Against Human Oral Squamous Carcinoma Xenograph in Nude Mice. Cancer Res. 1997, 57, 162168.

(39) Dhar, A.; Liu, S.; Klucik, J .; Berlin, K. D.; Madler, M. M.; Lu, S.; Ivey, R. T.; Zacheis, D.; Brown, C. W.; Nelson, E. C. Birckbichler, P. J .; Benbrook, D. M. Synthesis, StructureActivity Relationships, and RAR $\gamma$-Ligand Interactions of Nitrogen Heteroarotinoids. J. Med. Chem. 1999, 42, 3602-3614.

(40) Madler, M. M.; Klucik, I : Soell, P. S.; Brown, C. W.; Lui, S.; Berlin, K. D.; Benbrook, D. M.; Birckbichler, P. J .; Nelson, E. C. $\mathrm{LiOCl} / \mathrm{NaOCl}$ as a Novel Oxidative Mixture for Methyl Ketones and Methyl Carbinols. Org. Prep. Proc. Int. 1998, 30, 230-234.

(41) Benbrook, D. M.; Lu, S.; Flangan, C.; Shen-Gunther, J .; Angros, L. H.; Lightfoot, S. A. Biological Assay for Activity and Molecular Mechanism of Retinoids in Cervical Tumor Cells. Gyn. Oncol. 1997, 66, 114-121.

J M9902921 